\title{
Further Tests of Changes in Fish Escape Behavior Resulting from Sublethal Stresses Associated with Hydroelectric Turbine Passage
}

\section{April 2004}

Prepared by Michael G. Ryon Glenn F. Cada John G. Smith
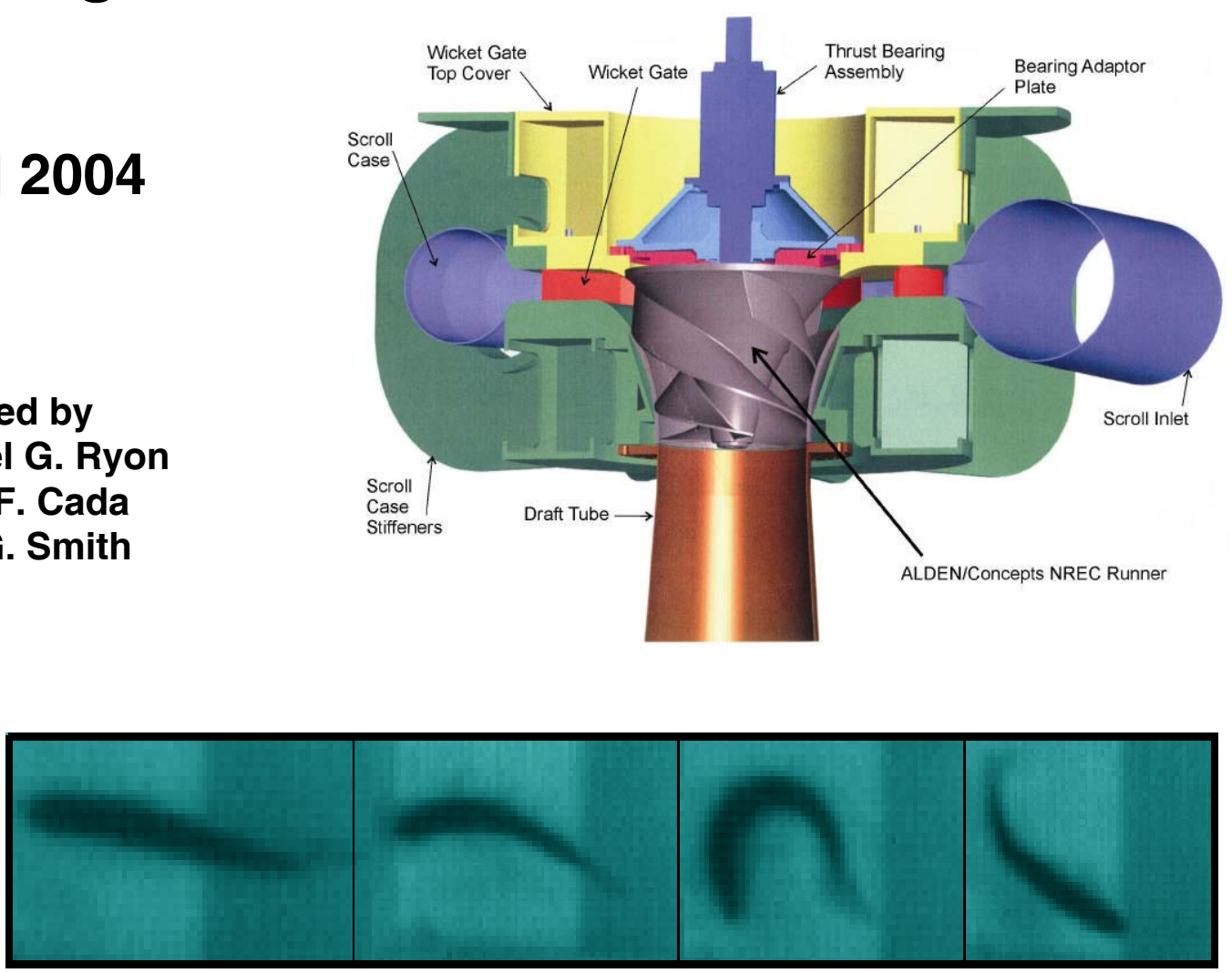

\section{U.S. Department of Energy}

Energy Efficiency and Renewable Energy

Wind and Hydropower Technologies

Bringing you a prosperous future where energy is clean, abundant, reliable, and affordable. 


\section{DOCUMENT AVAILABILITY}

Reports produced after January 1, 1996, are generally available free via the U.S. Department of Energy (DOE) Information Bridge.

\section{Web site http://www.osti.gov/bridge}

Reports produced before January 1, 1996, may be purchased by members of the public from the following source.

National Technical Information Service
5285 Port Royal Road
Springfield, VA 22161
Telephone 703-605-6000 (1-800-553-6847)
TDD 703-487-4639
Fax 703-605-6900
E-mail info@ ntis.fedworld.gov
Web site http://www.ntis.gov/support/ordernowabout.htm

Reports are available to DOE employees, DOE contractors, Energy Technology Data Exchange (ETDE) representatives, and International Nuclear Information System (INIS) representatives from the following source.

Office of Scientific and Technical Information

P.O. Box 62

Oak Ridge, TN 37831

Telephone 865-576-8401

Fax 865-576-5728

E-mail reports@adonis.osti.gov

Web site $\mathrm{http}: / /$ www.osti.gov/contact.html

This report was prepared as an account of work sponsored by an agency of the United States Government. Neither the United States Government nor any agency thereof, nor any of their employees, makes any warranty, express or implied, or assumes any legal liability or responsibility for the accuracy, completeness, or usefulness of any information, apparatus, product, or process disclosed, or represents that its use would not infringe privately owned rights. Reference herein to any specific commercial product, process, or service by trade name, trademark, manufacturer, or otherwise, does not necessarily constitute or imply its endorsement, recommendation, or favoring by the United States Government or any agency thereof. The views and opinions of authors expressed herein do not necessarily state or reflect those of the United States Government or any agency thereof. 
Environmental Sciences Division

\title{
FURTHER TESTS OF CHANGES IN FISH ESCAPE BEHAVIOR RESULTING FROM SUBLETHAL STRESSES ASSOCIATED WITH HYDROELECTRIC TURBINE PASSAGE
}

\author{
Michael G. Ryon \\ Glenn F. Cada \\ John G. Smith \\ Environmental Sciences Division \\ Oak Ridge National Laboratory
}

Date Published: April 2004

Prepared for

U.S. Department of Energy

Office of Energy Efficiency and Renewable Energy

Wind and Hydropower Technologies

Budget Activity Number EB 4400000

\author{
Prepared by \\ OAK RIDGE NATIONAL LABORATORY \\ P. O. Box 2008 \\ Oak Ridge, Tennessee 37831-6036 \\ managed by \\ UT-Battelle, LLC \\ for the \\ U.S. DEPARTMENT OF ENERGY \\ under contract DE-AC05-00OR22725
}





\section{CONTENTS}

LIST OF FIGURES $\ldots \ldots \ldots \ldots \ldots \ldots \ldots \ldots \ldots \ldots \ldots \ldots \ldots \ldots \ldots \ldots \ldots \ldots \ldots \ldots \ldots$

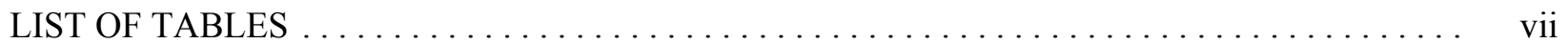

ACKNOWLEDGMENTS $\ldots \ldots \ldots \ldots \ldots \ldots \ldots \ldots \ldots \ldots \ldots \ldots \ldots \ldots \ldots \ldots$

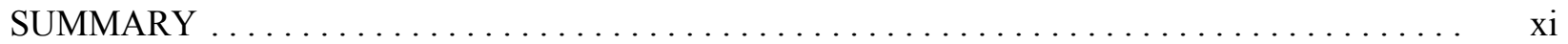

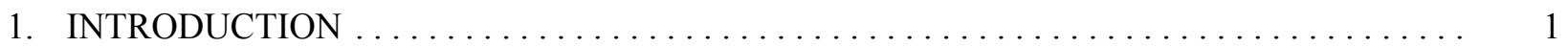

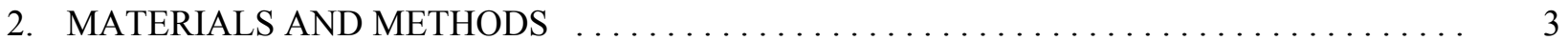

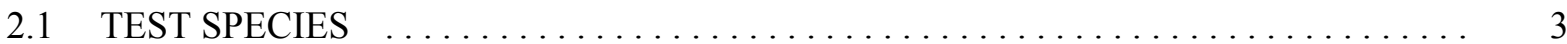

2.2 HOLDING TANK AND WATER CONDITIONS $\ldots \ldots \ldots \ldots \ldots \ldots \ldots \ldots \ldots \ldots$

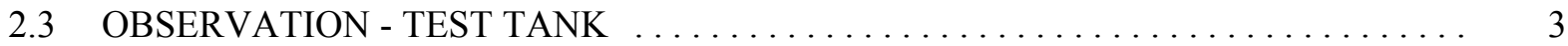

2.4 HIGH-SPEED CAMERA AND LIGHT CONDITIONS $\ldots \ldots \ldots \ldots \ldots \ldots \ldots \ldots \ldots$.

2.5 ALDEN RESEARCH LABORATORY TURBINE $\ldots \ldots \ldots \ldots \ldots \ldots \ldots \ldots \ldots \ldots \ldots$.

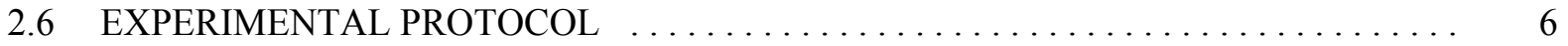

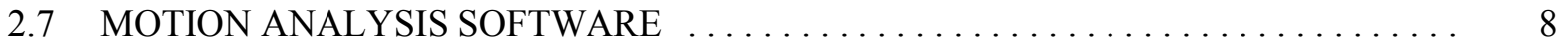

2.8 BEHAVIORAL MEASURES ANALYZED $\ldots \ldots \ldots \ldots \ldots \ldots \ldots \ldots \ldots \ldots \ldots$.

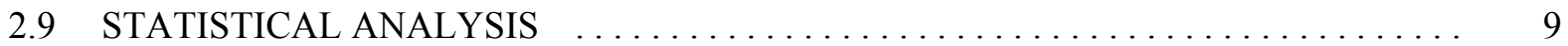

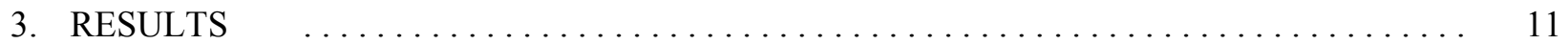

3.1 PRESENCE OF A REACTION TO TRIGGER $\ldots \ldots \ldots \ldots \ldots \ldots \ldots \ldots \ldots \ldots \ldots \ldots$

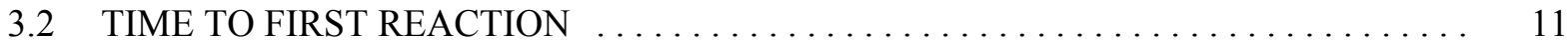

3.3 DURATION OF REACTION $\ldots \ldots \ldots \ldots \ldots \ldots \ldots \ldots \ldots \ldots \ldots \ldots \ldots \ldots \ldots \ldots \ldots \ldots$

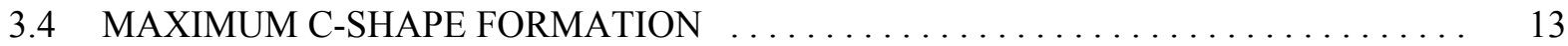

3.5 COMPLETENESS OF C-SHAPE FORMATION $\ldots \ldots \ldots \ldots \ldots \ldots \ldots \ldots \ldots \ldots \ldots$

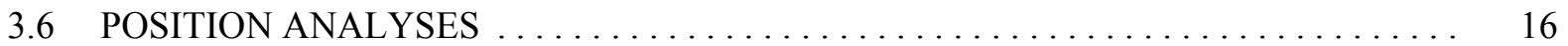

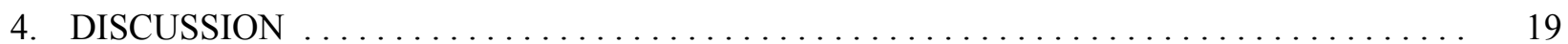

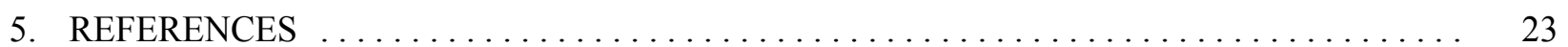

APPENDIX A: FISH BEHAVIOR DATA $\ldots \ldots \ldots \ldots \ldots \ldots \ldots \ldots \ldots \ldots \ldots \ldots \ldots \ldots$ 



\section{LIST OF FIGURES}

Figure

1.1 Schematic diagram of the $\mathrm{C}$-shape behavior in fish $\ldots \ldots \ldots \ldots \ldots \ldots \ldots \ldots \ldots \ldots \ldots$

2.1 Photo of observation tank showing (a) observation area coated with white fiberglass and (b) setup with side-mounted lights and automated startle trigger. . . . . . . . . . 4

2.2 Schematic of the Alden Research Laboratory turbine loop, showing injection

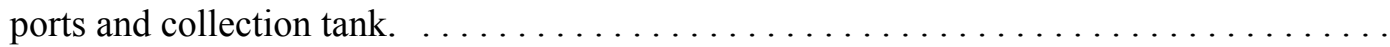

2.3 Net design to rapidly capture fish from Alden turbine loop collection tank (a) and allow fish to be scooped up (b) for use in observation tank $\ldots \ldots \ldots \ldots \ldots \ldots$

3.1 Mean time to first reaction for tank control, injection control, and turbine passed rainbow trout at the Alden turbine . . . . . . . . . . . . . . . . . . . . . . . . .

3.2 Mean duration of reaction for tank control, injection control, and turbine passed rainbow trout at the Alden turbine . . . . . . . . . . . . . . . . . . . . . . . .

3.3 Mean ratio of head-tail separation and body length for tank control, injection control, and turbine passed rainbow trout at the Alden turbine $\ldots \ldots \ldots \ldots \ldots \ldots \ldots$ 



\section{LIST OF TABLES}

Table

Page

2.1 Exposure/Transfer time (mean and range in $\min$ ) and mean time (min) that startle responses

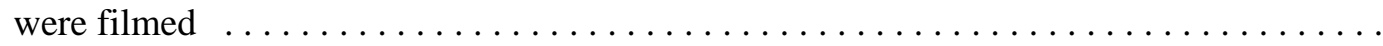

3.1 Fisher Exact tests of the independence of treatment and reaction of rainbow trout to a startle stimulus.

3.2 Behavioral reaction measurements of rainbow trout (Oncorhynchus mykiss) for holding tanks, controls, injection controls, or turbine passage $\ldots \ldots \ldots \ldots \ldots \ldots$

3.3 Summary of statistically significant differences in the escape behavior responses

of rainbow trout resulting from sublethal stresses

A.1 Repeated measures analysis of variance for time to first reaction to a startle stimulus,

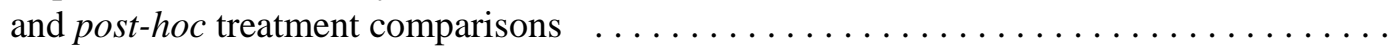

A.2 Analysis of variance of treatment effects, by startle stimulus time, for time to first

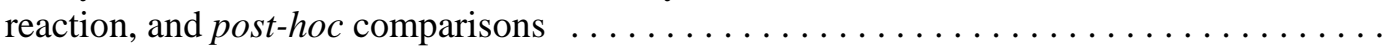

A.3 Repeated measures analysis of variance for duration of reaction following a startle

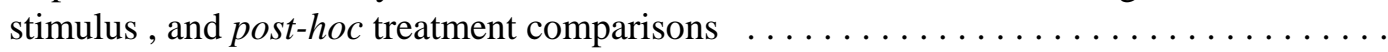

A.4 Analysis of variance of treatment effects, by startle stimulus time, for duration

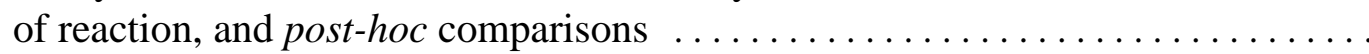

A.5 Repeated measures analysis of variance for time taken to form the maximum C-shape after a startle stimulus, and post-hoc treatment comparisons . . . . . . .

A.6 Analysis of variance of treatment effects, by startle stimulus time, for time taken to form the maximum C-shape, and post-hoc comparisons $\ldots \ldots \ldots \ldots \ldots \ldots$

A.7 Repeated measures analysis of variance for time taken from maximum C-shape to the end of C-shape behavior after a startle stimulus, and post-hoc treatment comparisons ....

A.8 Analysis of variance of treatment effects, by startle stimulus time, for time from maximum C-shape to the end of C-shape behavior, and post-hoc comparisons

A.9 Repeated measures analysis of variance for ratio of closest distance between head and tail: total body length

A.10 Chi-square tests of the independence of treatment and start position of fish to a startle stimulus 


\section{LIST OF TABLES (continued)}

A.11 Fisher Exact tests of the independence of start position of fish and exhibition of

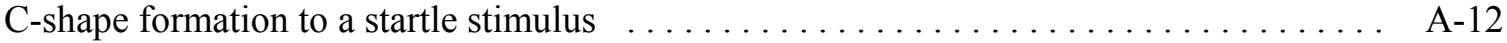

A.12 Fisher Exact tests of the independence of treatment and direction of turn from a startle

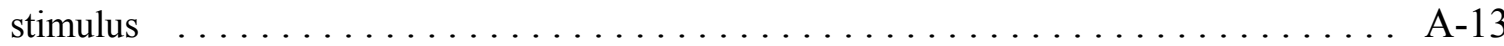

A.13 Fisher Exact tests of the independence of start position of fish and direction of turn

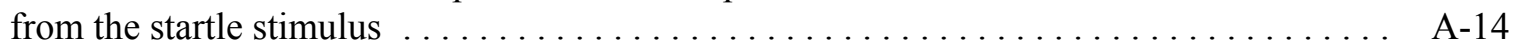

A.14 Fisher Exact tests of the independence of treatment and angle of turn following a

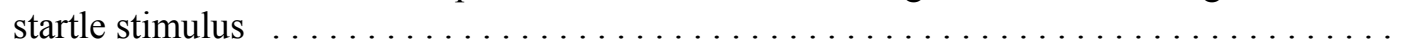

A.15 Fisher Exact tests of the independence of start position of fish and turn angle following a startle stimulus 


\section{ACKNOWLEDGMENTS}

We thank the staff of the ORNL Aquatic Laboratory for their assistance in designing and conducting these experiments. In particular, Kitty McCracken and Gail Morris helped run the fish exposures and analyze videos. Instrumentation assistance was provided by Jeff Riggs, Danny Sluss, Randy Smith, and Ed Stanford. During the on-site work at the Alden Laboratory, the assistance of Steve Amaral, Greg Allen, Tom Cook, Holly Frank, Brian McMahon, and Michelle Metzger of Alden Research Laboratory, Inc. made it possible to conduct experiments in the most efficient manner. The development of the fish capture netting was especially inspired. The schematic of the turbine, shown on the cover, is reprinted with the permission of Alden Research Laboratory, Inc. Valuable suggestions on the manuscript were provided by the Technical Committee of the U.S. Department of Energy's Advanced Hydropower Turbine Systems Program. The support of Peggy Brookshier, John Flynn, Jim Ahlgrimm, and Peter Goldman of the U. S. Department of Energy is greatly appreciated. This report is a product of the Office of Wind and Hydropower Technologies, Office of Energy Efficiency and Renewable Energy, U. S. Department of Energy. 



\section{SUMMARY}

Fish that pass through a hydroelectric turbine may not be killed directly, but may nonetheless experience sublethal stresses that will increase their susceptibility to predators (indirect mortality). There is a need to develop reliable tests for indirect mortality so that the full consequences of passage through turbines (and other routes around a hydroelectric dam) can be assessed. The most commonly used laboratory technique for assessing susceptibility to predation is the predator preference test. In this report, we evaluate the field application of a new technique that may be valuable for assessing indirect mortality, based on changes in a behavioral response to a startling stimulus (akin to perceiving an approaching predator).

The behavioral response is a rapid movement commonly referred to as a startle response, escape response, or C-shape, based on the characteristic body position assumed by the fish. When viewed from above, a startled fish bends into a C-shape, then springs back and swims away in a direction different from its original orientation. This predator avoidance (escape) behavior can be compromised by sublethal stresses that temporarily stun or disorient the fish.

Initial studies demonstrated that turbulence created in a small laboratory tank can alter escape behavior. As a next step, we converted our laboratory design to a more portable unit, transported it to Alden Research Laboratory in Holden, Massachusetts, and used it to test fish that passed uninjured through a pilot-scale turbine runner. Rainbow trout were either passed through the turbine or exposed to handling stresses, and their behavior was subsequently evaluated. Groups of five fish were given a startle stimulus (a visual and pressure wave cue) and filmed with a high-speed (500 frames per s) video camera. The reactions of each group of fish to the startle stimulus were filmed at nominally 1-, 5-, and 15-min postexposure. We compared the behaviors of 70 fish passed through the turbine and another 70 under control conditions (either transferred from the holding tank or injected into the Alden loop downstream of turbine).

The resulting image files were analyzed for a variety of behavioral measures including: presence of a startle response, time to first reaction, duration of reaction, time to formation of the maximum $\mathrm{C}$-shape, time to completion of the $\mathrm{C}$-shape, completeness of the $\mathrm{C}$-shape, direction of turn, and degree of turn. The data were evaluated for statistical significance and patterns of response were identified.

The most immediate measure of potential changes in fish behavior was whether test and control fish exhibited a startle response. Unlike earlier studies, there was no significant difference among the treatment group and the controls for startle response. The majority of rainbow trout in all groups responded to the startle stimulus. There were however, significant differences in some of the particular aspects of the subsequent escape behavior. The time to first reaction, the duration of the reaction, and the times associated with maximum C-shape formation were all significantly different between the tank controls and the two groups of fish injected into the Alden turbine loop. There were no significant differences in behavioral responses between the trout passed through the turbine runner and those injected downstream of the runner. Other behavioral parameters, such as C-shape completeness ratio, were not significantly affected.

The effect of the Alden turbine loop on some aspects of the escape behavior suggest that the process of movement through the system is important, but that the role of the added stress, if any, of passage through the turbine runner is minimal. It may be important that statistically significant differences in timing of phases of the startle response were detected, even though the majority of stressed fish still exhibited the startle response. This is in contrast to earlier studies, where timing of phases of the startle 
responses were only affected when the overall startle response was impaired. This pattern suggests that the escape behavior response can be a very sensitive tool for detecting potential effects of sublethal stresses associated with turbine passage. Field studies will be needed to determine whether such subtle changes would be translated into increased vulnerability to predation. If a link between changes in escape behavior and indirect mortality can be demonstrated in the field, this technique could become a rapid and inexpensive tool for assessing the total losses of fish at hydropower plants. 


\section{INTRODUCTION}

Many studies of downstream fish passage at hydroelectric power plants have focused on direct mortality, i.e., death directly due to injuries or physiological stresses received during passage through the turbine, spillways, or turbine bypasses. However, it is also recognized that turbine-passed fish may not be killed directly, and may appear to be uninjured, but nonetheless could experience sublethal stresses that could result in indirect mortality. For example, the immune system of stressed fish may be compromised such that they succumb to disease days or weeks after the passage stress occurred. On a shorter time scale, the swimming behavior of stressed fish may be altered in a way that makes them more susceptible to predators in the tailwaters. There is a need to develop reliable tests for indirect mortality so that the full consequences of passage through conventional and advanced turbines (and other routes around the hydroelectric dam) can be assessed. A technique was developed and tested in laboratory trials based on analysis of the behavioral response to predator threats (Cada et al. 2003).

The behavioral response is one form of fast-start swimming called the "C-start" (see Eaton and DiDomenico 1986; Webb 1986; Domenici and Blake 1997; Hale 1996). When viewed from above, a startled fish bends into a C-shape, then springs back and often swims away in a direction different from its original orientation (Figure 1.1). In the initial studies, predator avoidance (escape) behavior was compromised by either sublethal stresses of turbulence or a fish anaesthetic that temporarily stunned or disoriented the fish (Cada et al. 2003). The laboratory tests indicated that quantification of changes in escape behavior yielded results comparable to conventional, laboratory-based predator preference tests.

The purpose of this second phase of the study was to evaluate the potential of this technique for use in field-type application, with sublethal stresses that actually occur as a result of turbine passage. The technique was modified slightly from the approach used in the laboratory and tested on fish that passed through a pilot-scale version of a new turbine design at Alden Research Laboratory, Inc. (Alden) in Holden, Massachusetts. The study was designed to provide useful information on the field applicability of the technique and the potential for Alden's advanced turbine design to produce indirect mortality in turbine-passed fish. 


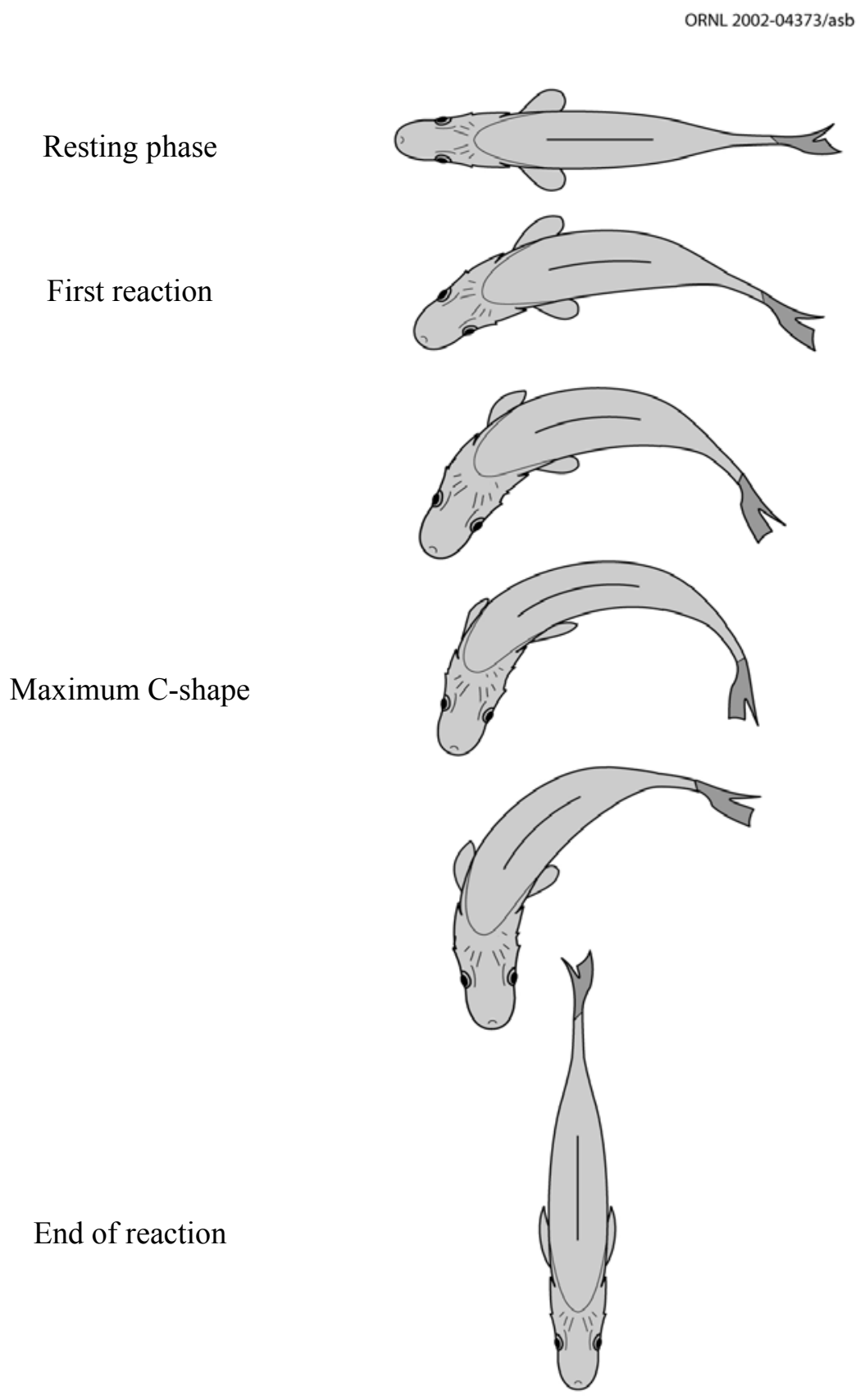

Fig. 1.1. Schematic diagram of the C-shape behavior in fish. 


\section{MATERIALS AND METHODS}

In previous laboratory experiments, the startle response test was conducted using two fish species and two primary stressors (Cada et al. 2003). Briefly, individual test fish were transferred from the holding tank to the observation tank, their initial response (escape behavior) to a startling stimulus was filmed with an overhead camera, they were given a sublethal stress, and their startle response was filmed again to try to detect changes in behavior. The species holding tanks, test and observation tank, camera, analysis and test procedures were the same or very similar for all the experiments.

In this study, the original test design was modified by using: (1) five test specimens during each trial, (2) a standardized, automatic startle trigger, (3) standardized, side-mounted lighting, (4) a uniform white coating in the tank, and (5) an overall equipment design that was easily transportable and would be suitable for a field application. The experiment was conducted during November 2002 at the Alden Research Laboratory (Alden) in Holden Massachusetts, using their pilot-scale turbine test facility (see Cook et al. 2003 and Section 2.5 of this report for a description). The test equipment was brought by car to Holden from Oak Ridge, Tennessee, with the aim to be as self-sufficient as possible. The revised test design examined fish from three groups: the holding tanks (tank-controls), fish injected into the loop upstream of the turbine (turbine-passed), and fish injected into the loop downstream of the turbine (injection-controls).

\subsection{TEST SPECIES}

The test species was the rainbow trout (Oncorhynchus mykiss). The trout were provided by Alden and were from the same stock used in Alden's evaluations of direct mortality of the turbine design. The trout had not been used for other experiments and ranged in size from 6 to $11 \mathrm{~cm}$ TL. The mean TL for each group was $8.6 \mathrm{~cm}$ for turbine-passed, $8.3 \mathrm{~cm}$ for injection controls, and $8.7 \mathrm{~cm}$ for tank controls.

\subsection{HOLDING TANK AND WATER CONDITIONS}

The Alden facility had a separate wing devoted to the fish holding tanks. The fish were kept in isolated holding tanks before testing and then transferred to a separate holding tank afterwards. This area was under a regulated light regime, and water was supplied continuously from local streams at ambient temperatures of $12 \mathrm{EC}$. The same water source supplied both holding tanks, observation tanks, and the turbine test loop. Further details about the holding tanks are provided in Cook et al. (2003) and Amaral et al. (2003).

\subsection{OBSERVATION - TEST TANK}

The observation tank was a single Living Stream ${ }^{\circledR}, 2.1 \mathrm{~m}$ long x $55 \mathrm{~cm}$ wide x $30 \mathrm{~cm}$ deep, that had been coated with white fiberglass to provide a uniform light background for observation (Figure 2.1a). Two plexiglass dividers created an observation area of $100 \mathrm{~cm} \times 55 \mathrm{~cm}$ (Figure $2.1 \mathrm{~b}$ ). This arena was the same size used in earlier studies (Cada et al. 2003). Water depth was restricted to $19 \mathrm{~cm}$ to limit vertical movements of test fish. Unlike the laboratory study, the water was not provided in a flow-through setup, but was kept static. Because the observation tank was located in the unheated portion of the test facility, water temperature was moderated by the cool air temperature and remained at 11-12EC throughout the test period. The water in the tank was aerated overnight to limit any oxygen deficit problems. 
(a)

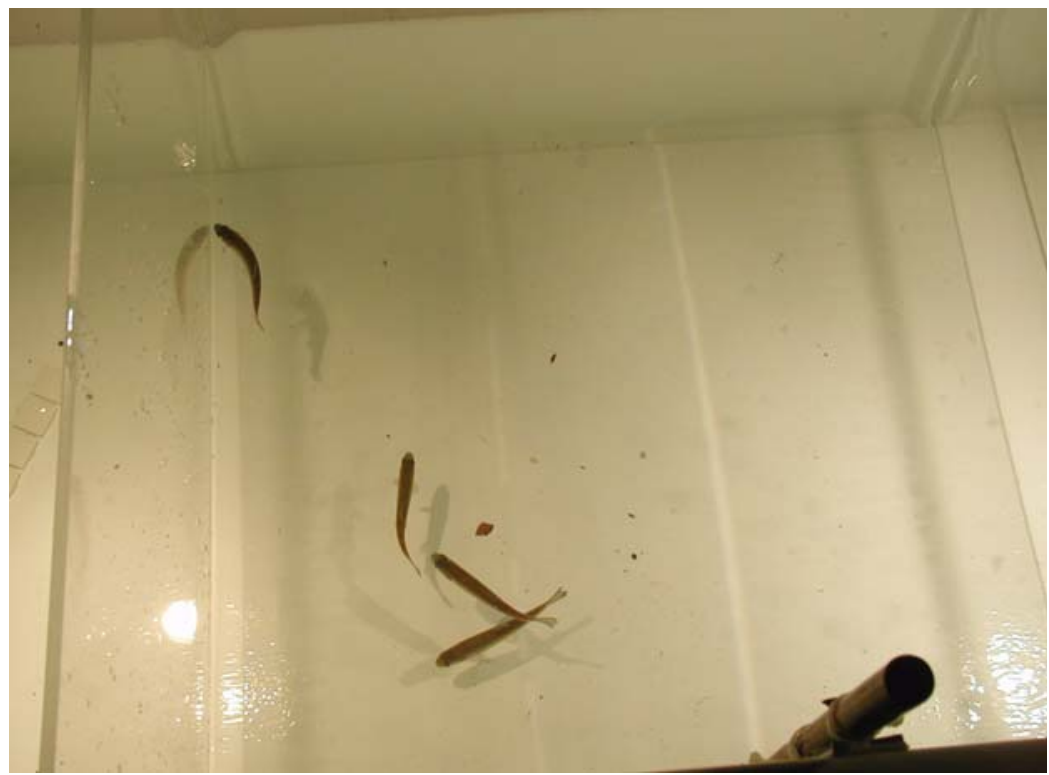

(b)

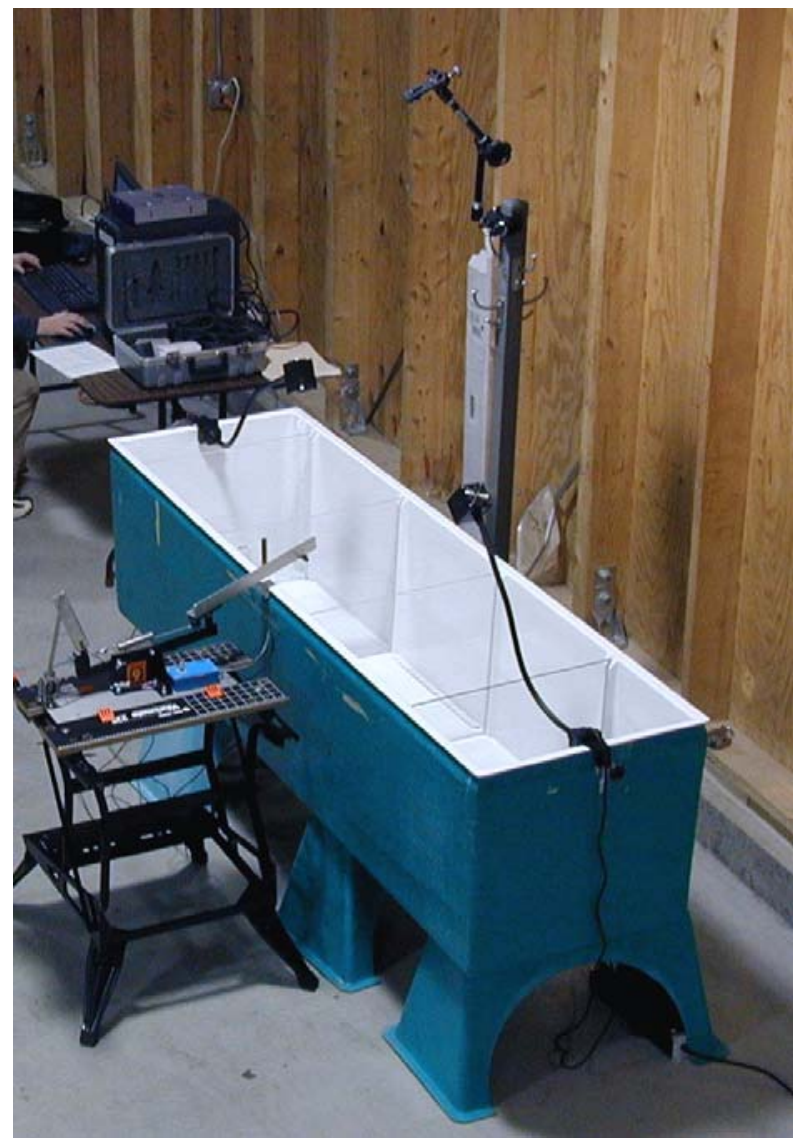

Figure 2.1. Photo of observation tank showing (a) observation area coated with white fiberglass and (b) setup with side-mounted lights and automated startle trigger. 


\subsection{HIGH-SPEED CAMERA AND LIGHT CONDITIONS}

Behavioral tests were recorded using a Photron Fastcam PCI ${ }^{\circledR}$, black and white, high-speed camera fitted with a $12.5-$ to $75-\mathrm{mm}$ zoom lens. Observations were digitally recorded at $500 \mathrm{fps}$ and a shutter speed of $1 / 10,000 \mathrm{~s}$. Images were saved as .AVI files on a personal computer with a maximum recording duration of $4.3 \mathrm{~s}$. The observation arena was lit with two tungsten halogen lights $(250 \mathrm{~W})$ designed for highspeed photography that were clamped on the sides of the observation tank (Figure 2.1b). The angled light provided more illumination, and less interference from glare or shadows than in the previous laboratory study.

\subsection{ALDEN RESEARCH LABORATORY TURBINE}

The Alden Research Laboratory's (Alden) turbine test facility was constructed to perform biological and engineering tests of the pilot scale Alden/Concepts NREC turbine runner (Cook et al. 2003; Amaral et al. 2003). The runner has a unique geometry that is believed to reduce the chance of entrained fish experiencing blade strike, extreme pressure changes and shear stresses. A 48-inch, pilot-scale turbine runner was installed in the turbine test facility at Alden and subjected to biological and engineering tests in 2001 and 2002.

The turbine test facility was designed to test the pilot-scale runner at an actual design head of about $80 \mathrm{ft}$ (24.4 m) (Cook et al. 2003), although many tests (including those described in this report) were conducted at a head of $40 \mathrm{ft}(12.2 \mathrm{~m})$. The facility includes a scroll case, wicket gates, turbine runner, draft tube, fish injection ports (upstream and downstream from the runner), and a fish collection tank (Figure 2.2). Water is recirculated through a closed loop. At a flow rate of $65 \mathrm{cfs}\left(1.82 \mathrm{~m}^{3} / \mathrm{s}\right)$, average velocities range from $9.7 \mathrm{ft} / \mathrm{s}(3.0 \mathrm{~m} / \mathrm{s})$ at the scroll inlet to $2.7 \mathrm{ft} / \mathrm{s}(0.8 \mathrm{~m} / \mathrm{s})$ in the expanded draft tube section downstream from the runner. However, actual velocities at any point vary from the cross-sectional average, particularly in the draft tube expansion area where flows may exhibit swirl and irregular changes in direction and velocity (turbulence).

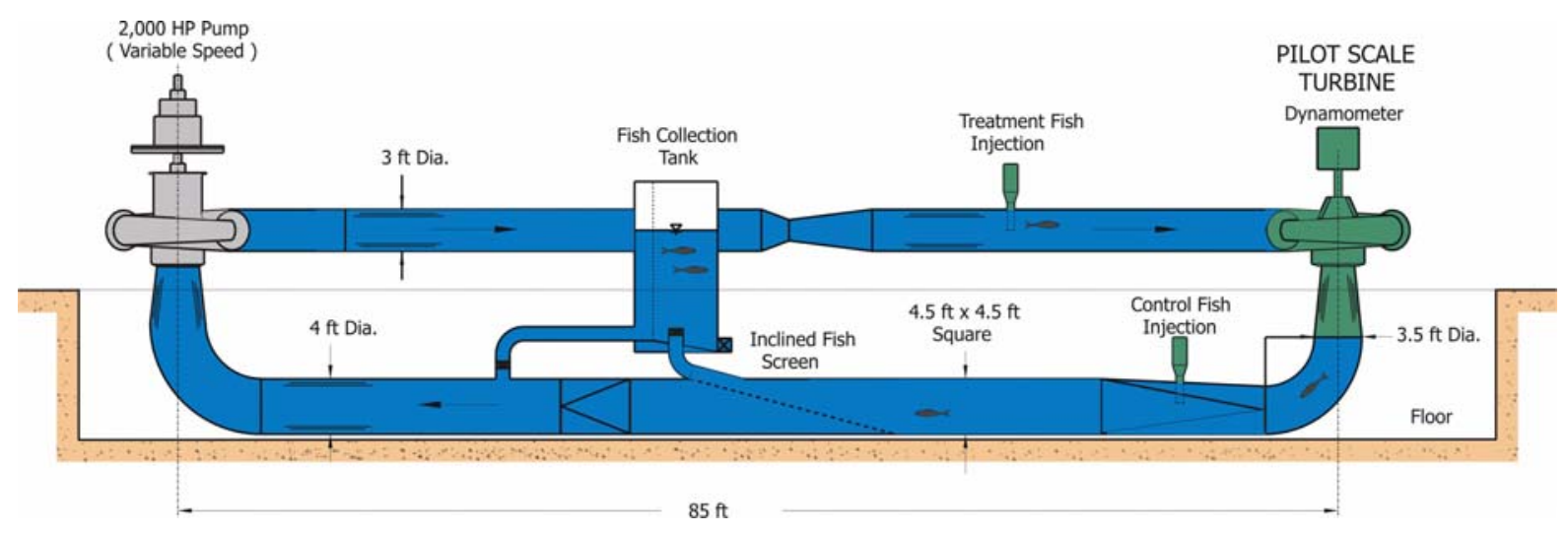

Figure 2.2. Schematic of the Alden Research Laboratory turbine loop, showing injection ports and collection tank. 
Fish may be injected into the test loop either upstream or downstream from the runner (Figure 2.2). Fish that are injected upstream from the runner pass through an area of flow constriction leading to the scroll case and runner. After exiting the runner, turbine-passed fish enter the draft tube, which expands in diameter from 2.8 to $5.5 \mathrm{ft}\left(0.85\right.$ to $1.68 \mathrm{~m}$ ) and turns the flow $90^{\circ}$ (Amaral et al. 2003). Injection-control fish enter the test loop downstream from the runner and draft tube bend; these fish experience the handling and pressure changes associated with injection, as well as some of the turbulence in the expanded section downstream from the draft tube, but not runner passage. Both turbine-passage and injection-control fish are recovered from the recirculating flow with an inclined collection screen and diverted into a large collection tank (Figure 2.2).

Although many of the potential fish injury mechanisms have been reduced in the new runner (e.g., blade strike, shear stress, and pressure changes), turbine-passed fish are exposed to an unknown amount of turbulence in the test loop, particularly where the flow path changes direction (at bends in the loop) or enters an expansion (from the draft tube to the inclined fish screen). By bending, twisting, or spinning the fish, this turbulence has the potential to cause injury, or at least temporary disorientation.

\subsection{EXPERIMENTAL PROTOCOL}

The experimental protocol compared the influence of passage through the Alden turbine (turbine passed) with control conditions as represented by fish injected into the loop downstream of the turbine (injection control) and fish transferred directly from the holding tanks to the observation area (tank control). A total of 140 fish were used for the treatment and control conditions. The fish were observed in groups of five per test, with 14 tests of the turbine passed, 10 tests of the injection control, and four tests of the tank control. For the tank control tests, five fish were transferred to the tank from a holding bucket, allowed to acclimate for one minute, and testing was initiated. For the fish exposed to the Alden turbine loop, the process was more involved. The fish were taken from the holding tanks in groups of 10, placed in an injection port (either upstream or downstream of the turbine), and forced into the flowing water by increasing air pressure in the injection port. Once in the flowing water of the loop, the fish injected upstream passed through the turbine runner and draft tube, and then went on downstream to a large collecting tank (Figure 2.2). The injection-control fish were exposed to the same handling stresses minus the passage through the turbine. Retrieving the fish from the collecting tank was facilitated by an innovative Alden-designed net that rested at the bottom of the tank (Figure 2.3a). Once an observer confirmed that at least five test fish had entered the fish collection tank, the net was quickly raised to the surface of the tank, trapping the fish which could then be scooped up with a dip net (Figure 2.3b) and transferred by bucket to the observation tank. The time from injection into the turbine loop and transferal to the observation tank ranged from 6 to $21 \mathrm{~min}$ (Table 2.1). The collection tank was then drained and the extra test fish that had been injected into the tank were collected and transferred to the post-testing holding tank; these fish were not used for further behavioral tests. Ten fish were used for each test to try to reduce the time needed to collect five fish for filming.

To initiate the startle response, an automated trigger was activated (Figure 2.1b). The trigger was based on a modified skeet trap launcher (spring-powered) that was released electronically and was synchronized with the start of filming. When activated, a 44-cm length of aluminum bar arced horizontally over the tank and struck a hollow pipe affixed to the side of the test tank. The trigger produced both a visual stimulus as it passed over the fish in the test arena and a shock/sound stimulus from contact with the pipe. Because the trigger was released electronically at the same time the camera began filming, the interval between stimulus and reaction was standardized. Also, because the trigger could be remotely released, the fish were not influenced by the presence of personnel next to the tank. 
(a)

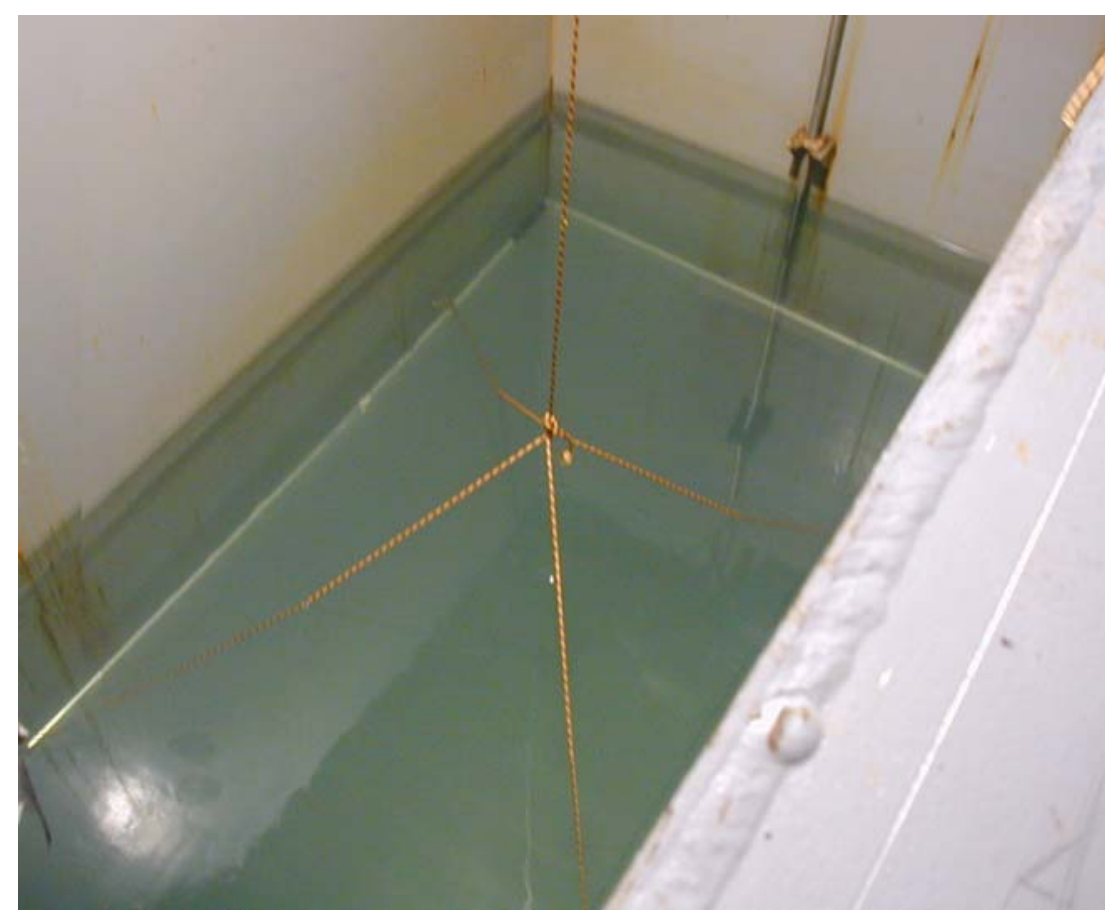

(b)

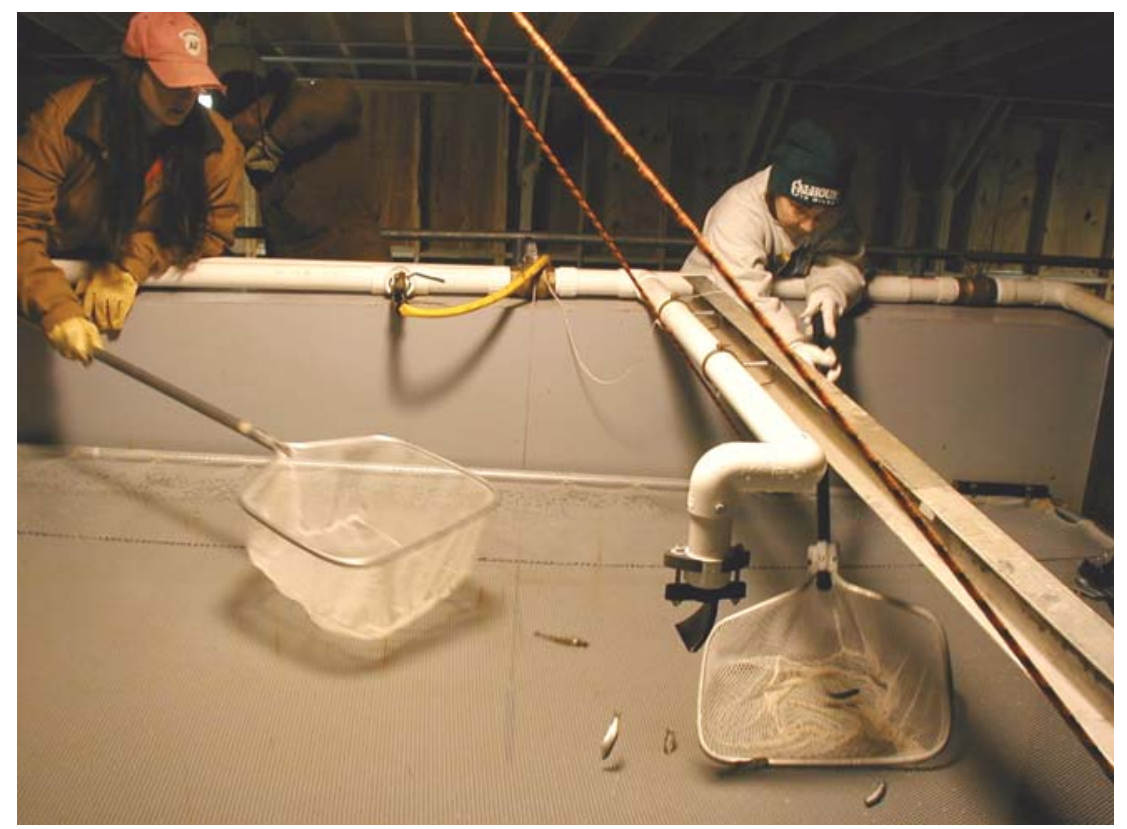

Figure 2.3. Net design to rapidly capture fish from Alden turbine loop collection tank (a) and allow fish to be scooped up (b) for use in observation tank.

Startle responses were filmed at nominally 1-, 5-, and 15-min post-transfer to determine whether fish startle response was affected by the treatment, and whether recovery occurred with time. After each test, the video image was saved to an .AVI file. Fish were used for only one test of stress exposure and then transferred to a post-experiment holding tank. Thirty minutes were required to accomplish an entire test series from transfer from the pre-test holding tank to exposures to post-stress recording steps. 


\section{Table 2.1 Exposure / transfer time (mean and range in min) and mean time (min) at which startle responses were filmed}

Times are measured from point where fish were injected into turbine loop (for injection control and turbine passage) or transferred from bucket (for tank control)

\begin{tabular}{lcccc}
\hline Test condition & $\begin{array}{c}\text { Exposure and } \\
\text { Transfer time }\end{array}$ & $\begin{array}{c}\text { T3 - } \\
\text { First Startle }\end{array}$ & $\begin{array}{c}\text { T4 - } \\
\text { Second Startle }\end{array}$ & $\begin{array}{c}\text { T5 - } \\
\text { Third Startle }\end{array}$ \\
\hline Tank control & 0 & 1 & 5 & 15 \\
Injection control & $10.4(6-21)$ & 11.4 & 15.0 & 25.8 \\
Turbine passage & $8.6(3-13)$ & 9.6 & 14.0 & 23.6 \\
\hline
\end{tabular}

\subsection{MOTION ANALYSIS SOFTWARE}

The movements of individual test fish were analyzed both by a frame-by-frame visual review $(0.002 \mathrm{~s}$ per frame) by an observer and an automated review using the commercial Visual Fusion ${ }^{\circledR}$ software program (vers. 3.2) designed by Sanders-Reed of Boeing-SVS, Inc. The program manually or automatically tracks targets in images created using high speed cameras. For our experiments, target fish were manually tracked by identifying the most anterior point of the head and the most posterior extension of the tail of their darkened silhouette and then the changes in distance between these points were measured as the escape behavior progressed.

\subsection{BEHAVIORAL MEASURES ANALYZED}

In the previous laboratory study, a suite of response indicators was evaluated for each test (Cada et al. 2003). Although the overall test was based on the startle or escape behavior, there are many phases to this process and it is not necessary that the full complement of the startle response be demonstrated to differentiate between treatments. Based on the results of the laboratory study, a subset of six measures were analyzed in the Alden study that had been used in the earlier study (1-6 below). Changes in any of these expressions of escape behavior could potentially affect a fish's vulnerability to predation. Besides

these measures, the fish behavior was also analyzed by examining five additional parameters (7-11 below) at the Alden Laboratory. These measures included:

1. reaction / no reaction,

2. time to first reaction,

3. duration of reaction,

4. time to maximum $\mathrm{C}$-shape formation,

5. time from maximum $\mathrm{C}$-shape to end of reaction,

6. completeness of C-shape (closest distance between head and tail divided by the total body length of the fish at rest),

7. whether the fish's starting position relative to the direction of the startle trigger (body parallel or perpendicular) influenced their reaction,

8. if the fish turned toward or away from the stimulus,

9. if the fish formed a recognizable $\mathrm{C}$-shape rather than just reacted to the startle,

10. whether the fish turned to the right or left, and

11. at what angle of escape the fish exited the C-shape, relative to its starting position. 
Unlike the laboratory study, repeated measurements of behavior of individual fish were not made, because the fish were not tagged individually. The fish behavior was analyzed for each group of five fish, with no attempt to follow individual fish through each startle event.

\subsection{STATISTICAL ANALYSIS}

The behavioral responses tested in these experiments included both categorical and measured responses, which influenced the type of statistical test that was used to detect significant differences. In categorical responses, frequencies of particular types of behavior are recorded. Such behaviors would include presence/absence of a response to a stimulus, or frequency of occurrence of specific responses. Measured responses include those in which specific measurements of test animals are taken during a fish's response to a stimulus. These measurements included the amount of time it took to react to a stimulus, or ratio of the distance between the head and tail at the point of maximum C-shape formation to the total body length. All statistical analyses were carried out with Statistical Analysis System (SAS) software and procedures (SAS Institute Incorporated, Cary, North Carolina, PC SAS Version 8.02).

Categorical responses tested in the experiment included (1) presence/absence of a reaction to a stimulus (i.e., yes/no), (2) influence of the starting position of a fish at the time of stimulus on the formation of a C-shape (yes/no response), (3) influence of the starting position on the direction of turn from the stimulus (frequencies of fish turning toward and away from a stimulus), and (4) influence of the starting position on the angle of directional change (frequencies of fish turning $0,45,90,135$, and 180 degrees). The null hypothesis for the presence/absence of a reaction to a stimulus was that the response was independent of treatment. Comparisons were made between the treatment and the two controls for each stimulus time (i.e., 1, 5, and $15 \mathrm{~min}$ ). Not all fish reacted to the stimulus during testing. Thus, analyses of C-shape formation, turn direction, and turn angle were made only on those fish reacting to a stimulus. Before testing each of these responses for their independence from start position, they first had to be tested for their independence from treatment effects. Comparisons were made between the treatment and the two controls for each stimulus time (i.e., 1, 5, and $15 \mathrm{~min}$ ). With acceptance of the null hypothesis of independence of formation of C-shape, direction of turn, and angle of turn from treatment effects, data from all treatments were pooled to test each response for its independence from start position.

Categorical responses were tested with a Chi-square test or Fisher Exact test, depending on the data structure. Chi-square tests may not be valid for small frequencies, in which case, a Fisher Exact text is usually recommended (Zar 1999). Additionally, the Fisher Exact test is the preferred test for $2 \times 2$ contingency tables, while the Chi-square test is most appropriate for larger contingency tables (Zar 1999).

In tests for which behavioral responses were measured on the same group of fish following a stimulus, each observation is not a replicate, but rather a repeated measure. Therefore, the appropriate statistical test is a repeated measures analysis of variance (ANOVA; Zar 1999). Measured behavioral responses that were tested included (1) time to first reaction to a stimulus (seconds), (2) duration of reaction following a stimulus (seconds), (3) time taken to form the maximum C-shape after a stimulus (seconds), (4) time to the end of C-shape behavior from the point of maximum C-shape formation (seconds), and (5) closest distance between head and tail at the maximum C-shape divided by total body length (the completeness of c-shape ratio). For each behavioral response, a repeated measures ANOVA, (SAS procedure PROC MIXED), was used to test for an overall treatment effect across the three stimulus times (i.e., 1, 5, 15 min). In contrast to the traditional means of calculating F-values (i.e., using ratios of mean squares), the PROC MIXED procedure uses restricted maximum likelihood estimates of the variance components to calculate the F-values (Littell et al. 1996). The MIXED procedure also provides a means for determining the most appropriate covariance structure for the data, thus providing more accurate tests 
(Littell et al. 1998). Finally, in contrast to the traditional procedure for a repeated measures ANOVA, the MIXED procedure can handle some forms of missing data without discarding all data for a subject that may have one or more missing data points.

Before running each test, the data were tested for normality and homogeneity of the variance with a Shapiro-Wilk test and Levene's test respectively (Zar 1999). In cases where the assumptions were not met, the data were transformed with either a log or square-root transformation. In those rare occasions when assumptions were still not met, analyses (e.g., box-plots) were performed to identify outliers, i.e., extreme values relative to other measurements (Zar 1999). After removal of outliers, the data were retested to determine if they met the assumptions. Removal of outliers resulted in a loss of no more than $5 \%$ of the data for any test response. Additionally, before testing the data for the overall effect of treatment, they were evaluated with a repeated measures ANOVA for trial-effects. This analysis looked for the possibility that a group of fish from a particular trial may not have responded similarly to other groups in trials tested under the same experimental conditions. Such an effect could add sufficient variability to the data to prevent detection of a treatment response. When trial-effects were detected, results from trials within the treatment group were further screened by examining the results from the LSMEANS option in PROC MIXED, which conducts an approximate t-test on the trial pairs; a Tukey's correction was used to adjust the p-values (http://math.uc.edu/ scl/computing/mixed.pdf). Trials potentially affecting the analysis were identified as those that were statistically different $(p<0.05)$ from two or more other trials. The data from identified trials were reexamined for additional outliers, and then reanalyzed for trial-effects after the removal of outliers. With identification and removal of outliers, the test for overall treatment effects was then made with a repeated measures ANOVA. When significant treatment effects were indicated, treatment differences were identified with the post-hoc test provided by the LSMEANS option for PROC MIXED. The resulting p-values were corrected with a Tukey's adjustment.

If a significant treatment effect was identified for a measured behavioral response, a one-way ANOVA, using the PROC GLM procedure, was used to test for treatment effects for each stimulus time. The factor of trial nested within treatment was included as a random factor in order to perform the appropriate F-test on treatment (Zar 1999). If significant differences were found, a Tukey's test was used to identify which treatments were different. 


\section{RESULTS}

In general, the escape behavior tests were conducted smoothly. The overall test protocol and the experimental tank design allowed us to conduct 28 tests over a 2-day period. Similarly, the camera and processing software worked virtually without fail. The few problems with the tests occurred partially as a result of this being the developmental phase of the overall test design. All of these were corrected and no systematic errors in the escape behavior tests were detected. A total of 140 rainbow trout were tested and evaluated for the standard behavioral responses.

\subsection{PRESENCE OF A REACTION TO TRIGGER}

Table 3.1 displays the numbers of rainbow trout that reacted to the startle stimulus at different times and under different treatment conditions. Most trout were startled by the stimulus trigger $(70 \%)$ and demonstrated a behavioral response, regardless of treatment or time since application of the treatment. There were no statistically significant differences between tank control, injection control and turbinepassed fish. The continued reaction to the startle stimulus did not indicate any habituation (relatively permanent reduction or elimination of a reaction to a repeated stimulus). Trout that did not react were not analyzed for other behavioral measures.

\subsection{TIME TO FIRST REACTION}

If a stressed fish is slow to react to a stimulus, even if it does react, it may not be able to escape an attack by a predator. Sublethal stresses may increase the time to first reaction following a startling stimulus. In our study, this parameter was easy to measure and it occurred consistently. For most fish, the first reaction was triggered by the sound - pressure wave associated with the bar hitting the tank, but some fish picked up the motion cue of the bar's movement toward the tank, and reacted prior to the strike. This suggests that the first reaction is a flight-based behavior, as it was triggered by more than one type of cue, and not just a random swimming motion. Also in the majority of cases, the first reaction progressed rapidly into a full $\mathrm{C}$-shape behavior.

The analysis of time to reaction for each group indicated that a majority of trout in all three groups reacted quickly (Table 3.2), generally within $0.5 \mathrm{sec}$, with the tank controls reacting quickest (Figure 3.1). Statistical analyses indicated that the tank controls reacted significantly faster than either injection controls or turbine passed fish (Table A.1). However, there was not a significant difference in reaction time between the fish passed through the turbine and those that were injected downstream of the runner. Apparently the increased turbulence of the system delayed the reaction time, but the additional stress of passing through the runner was only minimal. The pattern varied with time after stimulus; injection control and turbine-passed fish had significantly longer times to first reaction than tank controls at $1 \mathrm{~min}$ and $15 \mathrm{~min}$ post-treatment, but not at 5 min post-treatment (Table A.2).

\subsection{DURATION OF REACTION}

A stressed fish that stops its escape behavior too soon may still be captured by an attacking predator or if a prey fish over-reacts, then valuable energy resources may be wasted. A sublethal stress should not decrease the duration of reaction and without further predation threat, should not induce an increased duration of reaction. For our study, the duration reaction was another easily measured parameter that seemed fairly uniform in magnitude. The most difficult aspect of the parameter was delineating when the movement was complete. We applied a standard that the duration of the first reaction incorporated all movements, including a $\mathrm{C}$-shape, until the fish straightened out and began to coast, without tail fin movements. 


\section{Table 3.1. Fisher Exact tests of the independence of treatment and reaction of rainbow trout to a startle stimulus}

Values are frequencies and expected frequencies (in parentheses) of fish responses to the stimulus

\begin{tabular}{|c|c|c|c|c|c|}
\hline $\begin{array}{l}\text { Reaction to } \\
\text { stimulus }\end{array}$ & $\begin{array}{l}\text { Tank } \\
\text { control }\end{array}$ & $\begin{array}{l}\text { Injection } \\
\text { control }\end{array}$ & $\begin{array}{l}\text { Turbine } \\
\text { passed }\end{array}$ & $\begin{array}{l}\text { Row } \\
\text { total }\end{array}$ & $\begin{array}{l}\text { Statistical } \\
\text { values }\end{array}$ \\
\hline \multicolumn{6}{|c|}{1 min post-test startle stimulus } \\
\hline No & $\begin{array}{c}3 \\
(4.1)\end{array}$ & $\begin{array}{c}8 \\
(10.5)\end{array}$ & $\begin{array}{c}18 \\
(14.5)\end{array}$ & 29 & \multirow{3}{*}{$\begin{array}{c}\mathrm{df}=2 \\
\mathrm{p}=0.374\end{array}$} \\
\hline Yes & $\begin{array}{c}17 \\
(15.9)\end{array}$ & $\begin{array}{c}42 \\
(39.6)\end{array}$ & $\begin{array}{c}52 \\
(55.5)\end{array}$ & 111 & \\
\hline Column total & 20 & 50 & 70 & 140 & \\
\hline \multicolumn{6}{|c|}{5 min post-test startle stimulus } \\
\hline No & $\begin{array}{c}4 \\
(3.7)\end{array}$ & $\begin{array}{c}12 \\
(12.2)\end{array}$ & $\begin{array}{c}17 \\
(17.1)\end{array}$ & 33 & \multirow{3}{*}{$\begin{array}{c}\mathrm{df}=2 \\
\mathrm{p}=1.00\end{array}$} \\
\hline Yes & $\begin{array}{c}11 \\
(11.3)\end{array}$ & $\begin{array}{c}38 \\
(37.8)\end{array}$ & $\begin{array}{c}53 \\
(52.9)\end{array}$ & 102 & \\
\hline Column total & $15^{\mathrm{a}}$ & 50 & 70 & 135 & \\
\hline \multicolumn{6}{|c|}{15 min post-test startle stimulus } \\
\hline No & $\begin{array}{c}4 \\
(5.1)\end{array}$ & $\begin{array}{c}14 \\
(12.9)\end{array}$ & $\begin{array}{c}18 \\
(18)\end{array}$ & 36 & \multirow{3}{*}{$\begin{array}{c}\mathrm{df}=2 \\
\mathrm{p}=0.804\end{array}$} \\
\hline Yes & $\begin{array}{c}16 \\
(14.9)\end{array}$ & $\begin{array}{c}36 \\
(37.1)\end{array}$ & $\begin{array}{c}52 \\
(52)\end{array}$ & 104 & \\
\hline Column total & 20 & 50 & 70 & 140 & \\
\hline
\end{tabular}

${ }^{\mathrm{a}} \mathrm{An}$ initial delay in saving the image file from the $1 \mathrm{~min}$ post-test reaction required too much time to allow a test at 5 min post-test. Therefore, this observation period only had three test groups of 5 fish each.

The duration of the reaction in rainbow trout that were exposed to the Alden system was noticeably longer than the duration of reaction for trout in the control tank (Table 3.2; Figure 3.2). This reaction difference was statistically significant when tank controls were compared with injection controls and turbine-passed fish (Table A.3). Differences again were statistically significant at the 1-min and 15-min test periods, but not at the 5-min test period (Table A.4). Comparisons of reaction duration were not significantly different between the injection control and turbine passed fish, again indicating that the additional stresses of runner passage did not further alter this aspect of escape behavior. 


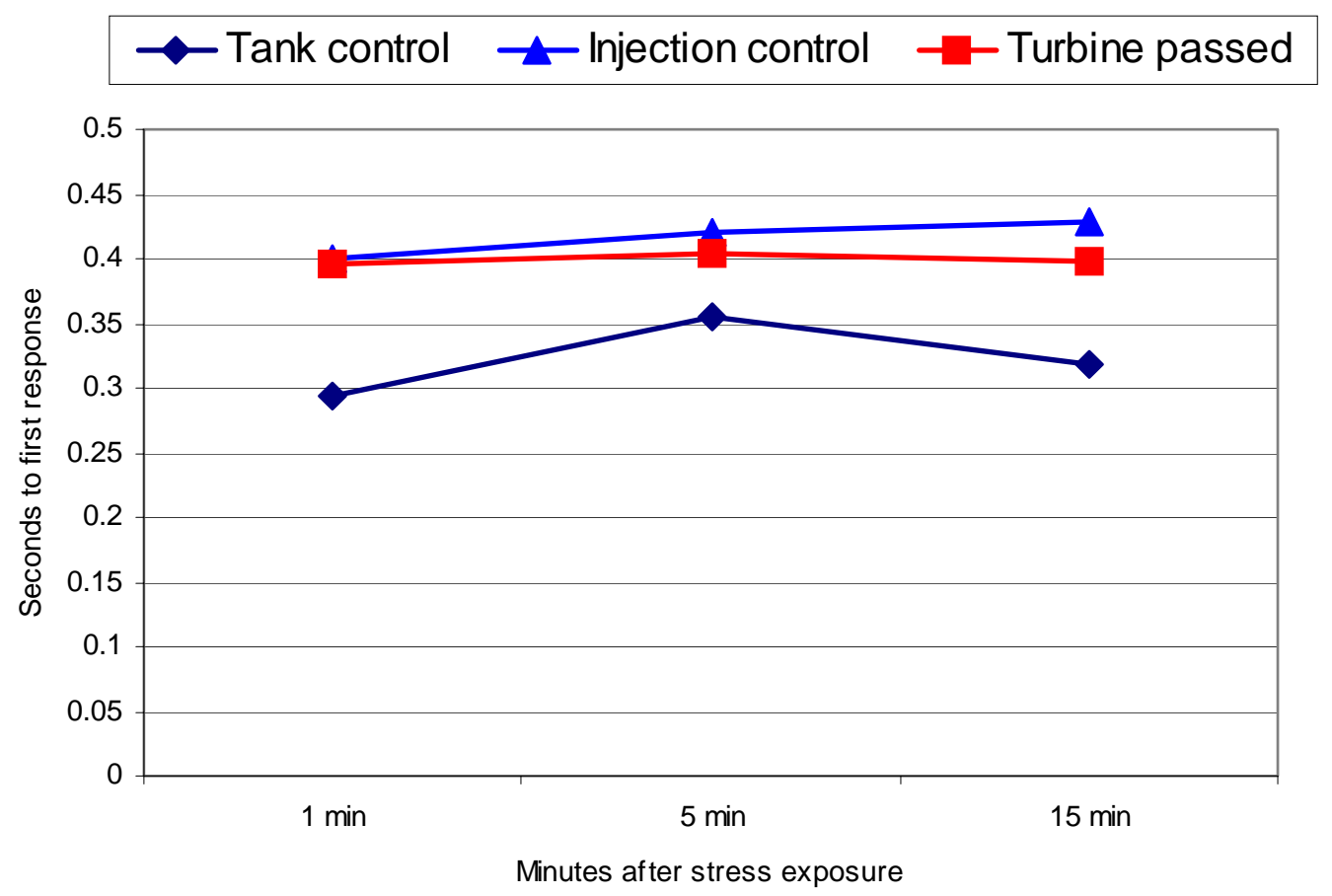

Figure 3.1. Mean time to first reaction for tank control, injection control, and turbine passed rainbow trout at the Alden turbine.

\subsection{MAXIMUM C-SHAPE FORMATION TIME}

A key element of escape behavior is the speed at which a startled prey can form into a C-shape and spring out again. If a sublethal stress increases the amount of time a fish takes to reach the maximum C-shape, the fish may not be able to escape the attacking predator. Similarly, if a fish does not have a rapid movement from the maximum C-shape to the end of the reaction, then it may not be generating sufficient speed to escape. In analyzing the video, it was easy to delineate the start and maximum C-shape positions in both control and treatment fish. The $\mathrm{C}$-shape formation behavior was also very similar between the rainbow trout and other species analyzed in earlier studies (Cada et al. 2003).

The reaction of the tank-control trout was much faster than either the injection control or turbine passed trout (Table 3.2). The pattern for time to maximum C-shape was statistically significant (Table A.5), being strongest at 1-min and 15-min tests (Table A.6) for both groups compared to tank controls. The time from maximum C-shape to end of reaction had a similar pattern (Table 3.2), but was only significant for the first (1-min) test period (Tables A.7 and A.8). As with other measures of escape behavior, the comparisons between injection control and turbine passed trout were not significantly different $(\mathrm{p}>0.05)$ in terms of times to and from maximum $\mathrm{C}$-shape. 
Table. 3.2. Behavioral reaction measurements of rainbow trout (Oncorhynchus mykiss) for holding tank controls, injection controls, or turbine passage

Outlying values were removed as appropriate and the values are mean $\pm \mathrm{SD}$

\begin{tabular}{|c|c|c|c|c|c|c|}
\hline $\begin{array}{l}\text { Type of } \\
\text { stressor }\end{array}$ & $\begin{array}{l}\text { Post-test } \\
\text { startle } \\
\text { stimulus } \\
\text { observation } \\
\text { time (min) }\end{array}$ & $\begin{array}{l}\text { Time to } \\
\text { first } \\
\text { reaction } \\
(\mathrm{s})^{\mathrm{a}}\end{array}$ & $\begin{array}{l}\text { Duration of } \\
\text { reaction }(\mathrm{s})^{\mathrm{b}}\end{array}$ & $\begin{array}{l}\text { Time to } \\
\text { max C- } \\
\text { shape } \\
\text { formation } \\
(s)^{c}\end{array}$ & $\begin{array}{l}\text { Time from } \\
\text { max } \\
\text { C-shape to } \\
\text { end of } \\
\text { reaction }(\mathrm{s})^{\mathrm{d}}\end{array}$ & $\begin{array}{c}\text { C-shape ratio } \\
\text { (Head-tail } \\
\text { distance: } \\
\text { total body } \\
\text { length) }\end{array}$ \\
\hline \multirow[t]{3}{*}{$\begin{array}{l}\text { Tank } \\
\text { control }\end{array}$} & 1 & $\begin{array}{c}0.293 \pm \\
0.033\end{array}$ & $\begin{array}{c}0.121 \pm \\
0.037\end{array}$ & $\begin{array}{c}0.027 \pm \\
0.017\end{array}$ & $\begin{array}{c}0.038 \pm \\
0.016\end{array}$ & $\begin{array}{c}0.676 \pm \\
0.196\end{array}$ \\
\hline & 5 & $\begin{array}{c}0.354 \pm \\
0.060\end{array}$ & $\begin{array}{c}0.156 \pm \\
0.058\end{array}$ & $\begin{array}{c}0.035 \pm \\
0.014\end{array}$ & $\begin{array}{c}0.061 \pm \\
0.034\end{array}$ & $\begin{array}{c}0.718 \pm \\
0.233\end{array}$ \\
\hline & 15 & $\begin{array}{c}0.318 \pm \\
0.048\end{array}$ & $\begin{array}{c}0.124 \pm \\
0.083\end{array}$ & $\begin{array}{c}0.035 \pm \\
0.028\end{array}$ & $\begin{array}{c}0.061 \pm \\
0.063\end{array}$ & $\begin{array}{c}0.652 \pm \\
0.211\end{array}$ \\
\hline \multirow[t]{3}{*}{$\begin{array}{l}\text { Injection } \\
\text { control }\end{array}$} & 1 & $\begin{array}{c}0.400 \pm \\
0.087\end{array}$ & $\begin{array}{c}0.254 \pm \\
0.167\end{array}$ & $\begin{array}{c}0.054 \pm \\
0.018\end{array}$ & $\begin{array}{c}0.070 \pm \\
0.032\end{array}$ & $\begin{array}{c}0.679 \pm \\
0.193\end{array}$ \\
\hline & 5 & $\begin{array}{c}0.420 \pm \\
0.116\end{array}$ & $\begin{array}{c}0.236 \pm \\
0.133\end{array}$ & $\begin{array}{c}0.059 \pm \\
0.024\end{array}$ & $\begin{array}{c}0.078 \pm \\
0.040\end{array}$ & $\begin{array}{c}0.667 \pm \\
0.184\end{array}$ \\
\hline & 15 & $\begin{array}{c}0.429 \pm \\
0.124\end{array}$ & $\begin{array}{c}0.195 \pm \\
0.077\end{array}$ & $\begin{array}{c}0.056 \pm \\
0.017\end{array}$ & $\begin{array}{c}0.075 \pm \\
0.035\end{array}$ & $\begin{array}{c}0.670 \pm \\
0.162\end{array}$ \\
\hline \multirow[t]{3}{*}{$\begin{array}{l}\text { Turbine } \\
\text { passed }\end{array}$} & 1 & $\begin{array}{c}0.396 \pm \\
0.076\end{array}$ & $\begin{array}{c}0.246 \pm \\
0.183\end{array}$ & $\begin{array}{c}0.049 \pm \\
0.023\end{array}$ & $\begin{array}{c}0.067 \pm \\
0.037\end{array}$ & $\begin{array}{c}0.706 \pm \\
0.180\end{array}$ \\
\hline & 5 & $\begin{array}{c}0.405 \pm \\
0.096\end{array}$ & $\begin{array}{c}0.246 \pm \\
0.159\end{array}$ & $\begin{array}{c}0.052 \pm \\
0.020\end{array}$ & $\begin{array}{c}0.080 \pm \\
0.041\end{array}$ & $\begin{array}{c}0.725 \pm \\
0.151\end{array}$ \\
\hline & 15 & $\begin{array}{c}0.399 \pm \\
0.098\end{array}$ & $\begin{array}{c}0.222 \pm \\
0.135\end{array}$ & $\begin{array}{c}0.053 \pm \\
0.018\end{array}$ & $\begin{array}{c}0.090 \pm \\
0.043\end{array}$ & $\begin{array}{c}0.661 \pm \\
0.161\end{array}$ \\
\hline
\end{tabular}

${ }^{\mathrm{a} E x c l u d e s}$ values $>0.5$ for tank control, $<0.22$ for injection control, and $<0.22$ and $>0.65$ for turbine passed fish.

${ }^{b}$ Excludes two tests for turbine passed fish.

${ }^{c}$ Excludes values $>0.13$.

${ }^{\mathrm{d} E x c l u d e s}$ values $\$ 0.2$ for injection control fish. 

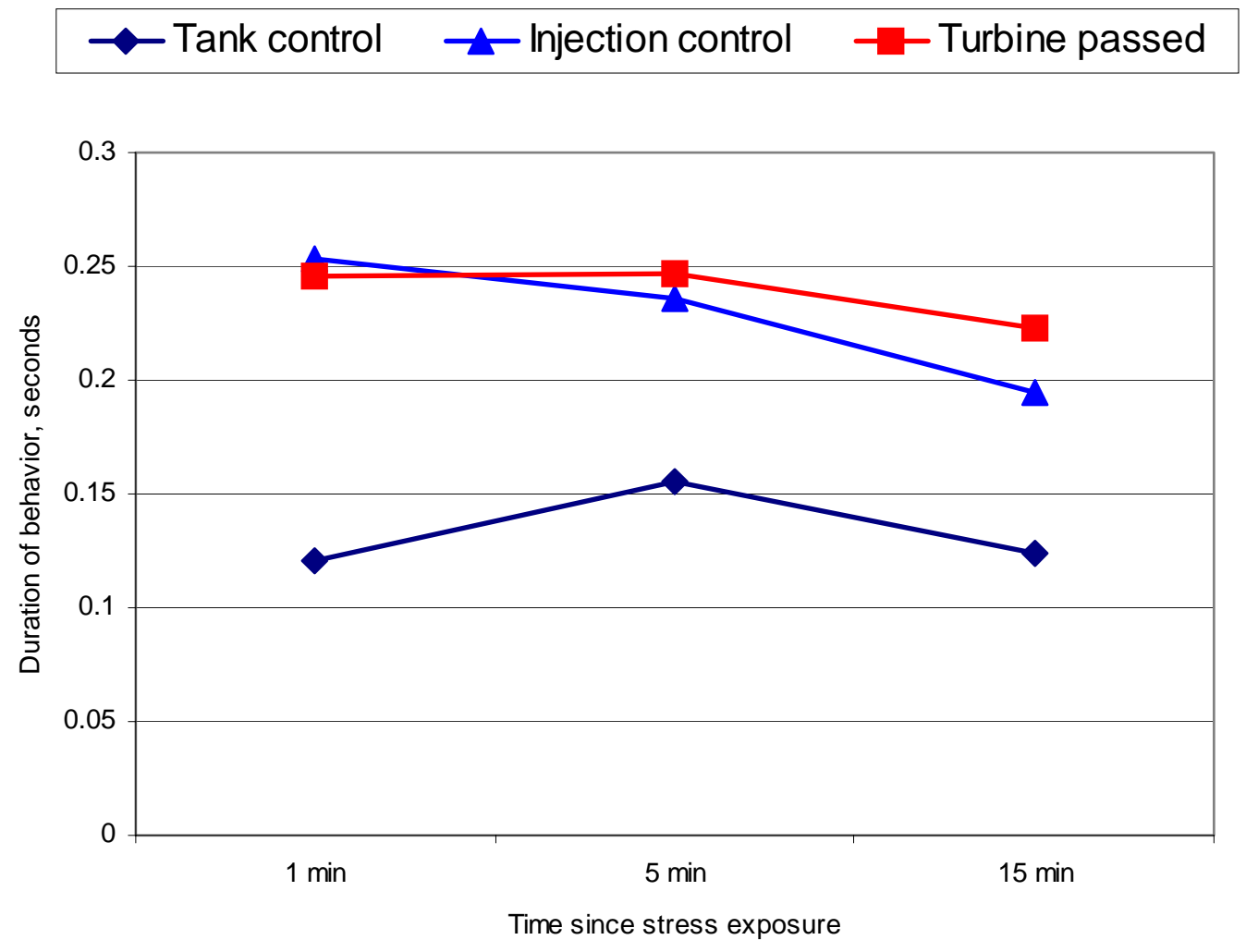

Figure 3.2. Mean duration of reaction for tank control, injection control, and turbine passed rainbow trout at the Alden turbine.

\subsection{COMPLETENESS OF C-SHAPE FORMATION}

The completeness of the C-shape has an influence on the speed of the prey's escape maneuver. If a fish forms a strong C-shape, it will have more power and velocity when it springs out again than a fish that only flexes a small amount before swimming away. That is, if a sublethal stress reduces the completeness of the C-shape, the startled prey fish may not have enough propulsive power (speed) to escape an attack. Also, a more complete $\mathrm{C}$-shape will allow the prey to choose several directions in which to escape. As the fish springs out it can alter the path of escape so it may change its heading by 0 to $180 \mathrm{E}$ We expressed completeness of $\mathrm{C}$-shape as the ratio of the head-to-tail distance at the point of maximum $\mathrm{C}$ shape formation to the total length of the fish. The ratio could range from 1.0 (fish does not bend at all, so the head-to-tail distance is the same as the total length) to 0.0 (the head and tail touch at the peak of the $\mathrm{C}$-shape formation, so that the head-to-tail distance is zero). We assume that the smaller the ratio, the more power and speed the fish can exert when escaping a startling stimulus. This was an easily measured parameter, only slightly more difficult to determine on small fish, or fish where the tail was hard to detect in the image. 

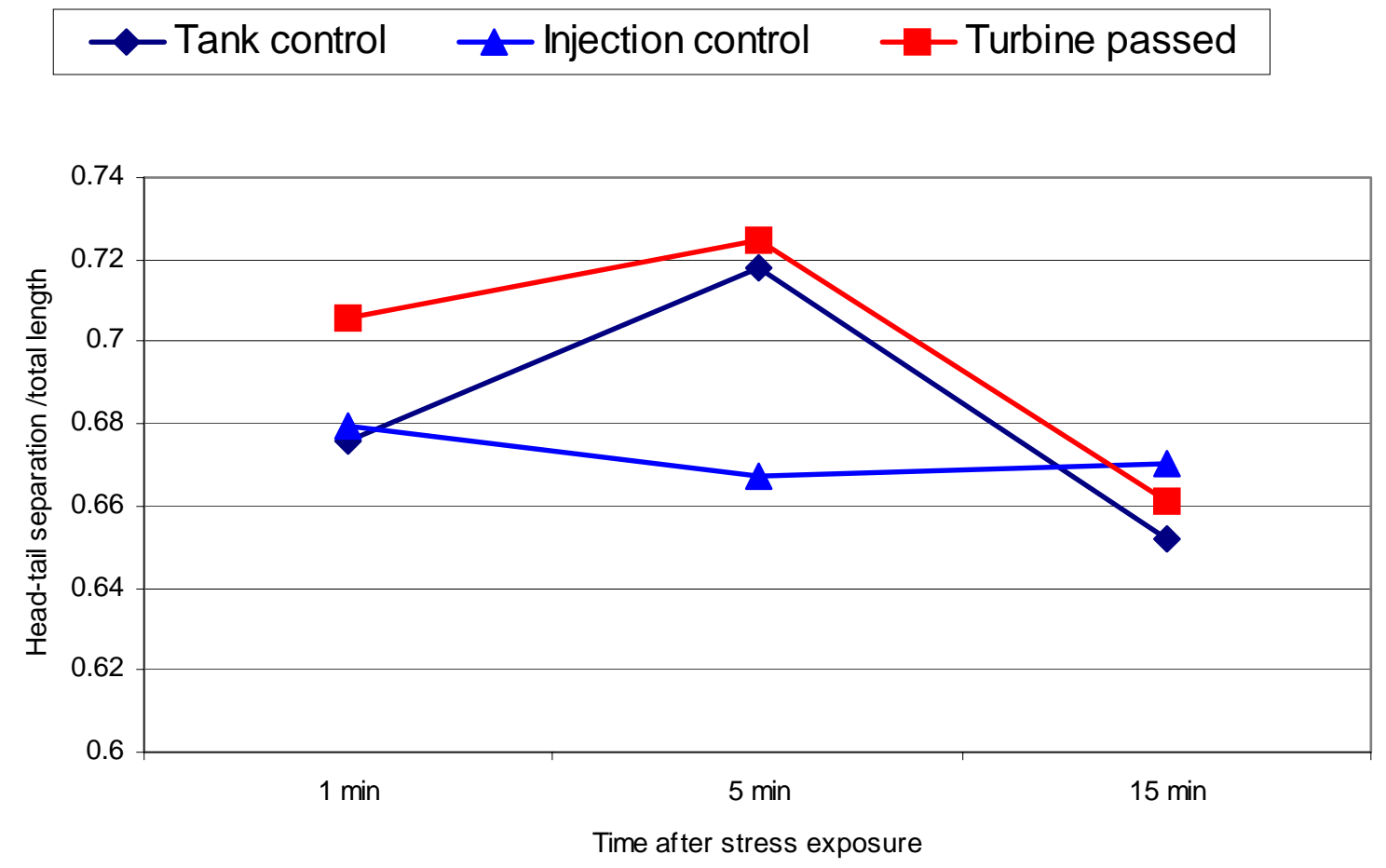

Figure 3.3. Mean ratio of head-tail separation and body length for tank control, injection control, and turbine passed rainbow trout at the Alden turbine.

In contrast to other measures of escape behavior, the completeness of the C-shape did not differ significantly among test groups (Table 3.2; Figure 3.3; Table A.9). The lack of a significant difference between treatment and control groups for this measure supports the general low impact of the stress originally indicated by the non-significant pattern seen for response vs. no-response analysis.

\subsection{POSITION ANALYSES (START POSITION, TURNING DIRECTION, ESCAPE ANGLE)}

As part of the analysis of escape behavior as an evaluation tool, we looked at the various factors associated with position of the test fish in the observation tank during the startle event. It seemed possible that the position of a test fish when the startle stimulus occurred could affect the degree of its response, or the type of response demonstrated. For example, if a fish was parallel to the side of the tank where the trigger bar hit, so that the entire lateral line of the fish was broadside to the pressure wave, would the fish react more than if it was perpendicular to the oncoming pressure wave? Similarly, would a stressed fish be more likely to turn toward the pressure wave or would it turn at a smaller angle than a non-stressed fish? These reactions could be important in deciding whether a fish is eaten or not. Therefore, we looked at three additional measures of behavior, all related to position.

The reacting trout in the treatment and control groups were analyzed to see if there was a significant difference in their reaction depending on whether they were oriented parallel or perpendicular to the side of the tank where the startle trigger occurred. The analysis indicated that the orientation of the fish had no significant impact on the reaction of a test fish (Table A.10). Further, there were no significant 
relationships between starting position and completeness of the C-shape formed (Table A.11). These analyses indicated that we did not have to be concerned about a test fish's body orientation for other analyses.

We examined whether the direction a fish turned when it reacted to the stimulus was related to the level of stress. The movement of the trout was categorized as toward or away from the stimulus, and this movement was also related to its position (parallel or perpendicular) to the startle trigger. There were no statistically significant differences between treatment or control groups for direction of movement (Table A.12) or movement related to starting position (Table A.13).

Finally, we looked at the magnitude of the turn angle that a trout made after being startled. The turns were classified as $0-180 \mathrm{E}$ which reflected the change in head orientation from the starting position to the final position during the escape maneuver. There were no statistically significant relationships between treatment and turning angle (Table A.14) or angle and start position (Table A.15). 



\section{DISCUSSION}

The studies we conducted in the Alden turbine were designed to evaluate the effects of passage through this pilot-scale turbine on various elements of the escape behavior, which in turn may be an indicator of indirect mortality in river systems. Earlier laboratory studies have shown that the behavior is influenced by stress and can provide a sensitive, repeatable marker of that stress (Cada et al. 2003). The laboratory studies used fairly intense levels of turbulence or heavy doses of anesthetic to produce altered behavior. In most real world situations, the levels of stress may not be as intense or may be of shorter duration. However, real world tests of changes in escape behavior among turbine-passed fish might be limited by the speed at which stressed fish could be recovered for a behavioral evaluation. Therefore, we chose to evaluate less intense, shorter durations of turbulence stress using the pilot-scale turbine at the Alden Laboratory.

In the earlier laboratory studies, a key effect was the complete absence of a startle response in many of the stressed fish. At Alden, the trout did not exhibit a significant total disruption of the startle response. Nor did the treatments at Alden affect the trout's ability to competently form a C-shape. From these behavioral evaluations, it appears that the potential for increased indirect mortality associated with a Alden-type turbine design may be minimal. Most fish should still be able to react to predatory threats soon after passage.

However, the sublethal stresses experienced in the Alden turbine loop were not totally without effect on the trouts' escape behavior. The increased activity and stress associated with being injected into the loop, dealing with the high flows, and being netted from the collection tank, affected some performance aspects of the escape behavior. The reaction times, duration of reaction, and times required to form and release the C-shape all were significantly affected for the trout introduced into the Alden turbine loop (Table 3.3). The disruption of the escape behavior timing also was not limited to just the first 1-min test evaluation, and often was significantly changed at the 15-min startle evaluation as well. Because of the time required to remove fish from the collection tank, the 15-min startle evaluation was at an average of nearly 24 minutes after turbine passage. Thus, although the alteration of the escape behavior in the Alden study was more subtle than in laboratory studies, the duration of the effect was more extended. Comparison of fish passed through the runner with those introduced into the loop downstream of the runner indicated that the additional stresses of passage through the pilot-scale turbine did not significantly affect trout any more than other aspects of the loop experience.

One of the concerns about using the escape behavior technique at the Alden turbine test facility was the amount of time required to retrieve injection controls and runner-passed fish. An average of about 10 minutes elapsed from when fish were injected into the test loop (either upstream or downstream from the runner) until they were removed from the fish collection tank and transferred to our observation tank. Because some of that time is spent in the relatively quiet waters of the loop's fish collection tank, there is an opportunity for disoriented fish to recover before escape behavior testing. Earlier laboratory escape behavior tests with two minnow species found that changes in escape behavior that were obvious within a few minutes of the treatment moderated with time. Application of sublethal doses of turbulence or anesthetic significantly reduced the proportions of shiners and minnows that reacted to a startling stimulus, but after 1-5 minutes the proportions were not different from control fish (Cada et al. 2003).

In the Alden tests reported here, some aspects of the escape behavior of uninjured rainbow trout that passed through the pilot-scale runner were diminished compared to controls at the first post-test period, about 10 minutes after runner passage. Further, these statistically significant changes in escape behavior were still detected in tests up to 15 minutes later. Because the reductions in escape behavior brought 
Table 3.3. Summary of statistically significant differences in the escape behavior responses of rainbow trout resulting from sublethal stresses

\begin{tabular}{|c|c|c|c|}
\hline Measure of escape behavior & $\begin{array}{c}\text { Tank control } \\
\text { vs Injection } \\
\text { control }\end{array}$ & $\begin{array}{c}\text { Tank control } \\
\text { vs Turbine } \\
\text { passed }\end{array}$ & $\begin{array}{l}\text { Injection control } \\
\text { vs Turbine passed }\end{array}$ \\
\hline \multicolumn{4}{|c|}{$1 \mathrm{~min}$ post-test startle stimulus } \\
\hline Presence / absence of startle response & No & No & No \\
\hline Time to first reaction & Yes & Yes & No \\
\hline Duration of reaction & Yes & Yes & No \\
\hline Start to max C-shape & Yes & Yes & No \\
\hline Max C-shape to end & Yes & Yes & No \\
\hline C-shape ratio & No & No & No \\
\hline \multicolumn{4}{|c|}{5 min post-test startle stimulus } \\
\hline Presence / absence of startle response & No & No & No \\
\hline Time to first reaction & No & No & No \\
\hline Duration of reaction & No & No & No \\
\hline Start to max C-shape & No & Yes & No \\
\hline Max C-shape to end & No & No & No \\
\hline C-shape ratio & No & No & No \\
\hline \multicolumn{4}{|c|}{15 min post-test startle stimulus } \\
\hline Presence / absence of startle response & No & No & No \\
\hline Time to first reaction & Yes & Yes & No \\
\hline Duration of reaction & Yes & Yes & No \\
\hline Start to max C-shape & Yes & Yes & No \\
\hline Max C-shape to end & No & No & No \\
\hline C-shape ratio & No & No & No \\
\hline
\end{tabular}

about by sublethal stressors like turbulence may be short-lived (but nonetheless fatal if a predator is encountered a few minutes after exposure), it is important to retrieve and measure stressed fish as quickly as possible. The absence of a statistically significant difference between tank controls and the other groups for presence/absence of a startle response may have resulted from this delay in behavior testing. This suggests that detection of all relevant changes in fish escape behavior in field applications would be 
very difficult. However, the continued disruptions of some of the performance parameters (e.g., time to first reaction) over a longer period of time suggest that field trials could be effective as long as fish are retrieved and tested as quickly as possible.

A key question in assessing the impact of the Alden turbine on changes in escape behavior of the trout is whether the significant changes in performance parameters would translate to an increase in predation susceptibility. In theory, a fish's continued ability to react to a startle stimulus and to form a strong Cshape should provide some escape capacity. However, if a fish is too slow to form or spring back out of the C-shape, a predator may have gained enough of an advantage to decrease the survivability of the prey. A predatory strike is usually very rapid, in pike (Esox) lasting 0.1- 0.2 s (Webb and Skadsen 1980). A pike can travel a distance of $10 \mathrm{~cm}$ in $0.1 \mathrm{~s}$ (Webb 1978). Because studies of feeding strike (Domenici and Blake 1997) indicate a predator can strike a prey within $0.2 \mathrm{~s}$ of commencing its attack, the delay in reaction time we observed may be significant biologically. This question cannot be answered with the data presented in this report. We do not know the relative importance of the change in performance capabilities demonstrated by this study. In our laboratory studies we were able to compare the escape behavior results with a concurrent predator preference study to verify that the turbulence stresses that impaired behavior also resulted in an actual increase in predation rate. At the Alden site, we were unable to combine a predator preference test with the behavior test for verification. In most cases, this situation would be true for field studies conducted with downstream passage of fish at a hydroelectric facility.

The relationship between the disruption of the escape behavior and the influence of the hydraulic environment of a hydropower facility appears to be useful enough that implementation of this tool should be evaluated further. If passage around or through a hydropower facility disrupts the overall escape behavior or affects the individual timing of escape reactions, then increased mortality could be a result. Because the indirect mortality associated with such facilities is an unknown, but potentially very significant, component of the reduced survival of salmon, application of this tool may help further define the problem. Further steps in the evaluation of the use of escape behavior as an indicator of indirect mortality could include: 1) additional comparisons of escape behavior and predator-feeding studies after exposure to a known, or better characterized, source of turbulence; 2) evaluations of escape behavior in more fish species; and 3) evaluations of escape behavior at fully functioning hydropower facilities using real passage conditions. 



\section{REFERENCES}

Amaral, S., G. Hecker, M. Metzger, and T. Cook. 2003. 2002 biological evaluation of the Alden/Concepts NREC turbine. Proceedings of Waterpower XIII. HCI Publications, Inc. Kansas City, MO.

Cada, G.F., M. G. Ryon, D.A. Wolf, and B. T. Smith. 2003. Development of a new technique to assess susceptibility to predation resulting from sublethal stresses (indirect mortality). ORNL/TM-2003/195. Oak Ridge National Laboratory, Oak Ridge, TN. (Prepared for the U.S. Department of Energy, Office of Energy Efficiency and Renewable Energy, Office of Wind and Hydropower Technologies).

Cook, T.C., G. E. Hecker, S. V. Amaral, P. S. Stacy, F. Lin, and E. P. Taft. 2003. Draft Final Report Pilot Scale Tests Alden/Concepts NREC Turbine. Prepared by Alden Research Laboratory, Inc. for the U.S. Department of Energy Office of Energy Efficiency and Renewable Energy, Office of Wind and Hydropower Technologies.

Domenici, P. and R.W. Blake. 1997. The kinematics and performance of fish fast-start swimming. The Journal of Experimental Biology 200:1165-1178.

Eaton, R.C. and R. DiDomenico. 1986. Role of the teleost escape response during development. Transactions of the American Fisheries Society 115:128-142.

Hale, M.E. 1996. The development of fast-start performance in fishes: Escape kinematics of the chinook salmon (Oncorhynchus tshawytscha). American Zoologist 36:695-709.

Littell, R. C., P. R. Henry, and C. B. Ammerman. 1998. Statistical analysis of repeated measures data using SAS procedures. Journal of Animal Science 76:1216-1231.

Littell, R. C., G. A. Milliken, W. W. Stroup, and R. D. Wolfinger. 1996. SAS System for mixed models. SAS Institute Inc., Cary, North Carolina.

Webb, P. W. 1978. Fast-start performance and body form in seven species of teleost fish. The Journal of Experimental Biology 74:211-226.

Webb, P. W. 1986. Effect of body form and response threshold on the vulnerability of four species of teleost prey attacked by largemouth bass (Micropterus salmoides). Canadian Journal of Fisheries and Aquatic Sciences 43:763-771.

Webb, P. W. and J. M. Skadsen. 1980. Strike tactics of Esox. Canadian Journal of Zoology 58:1462-1469.

Zar, J. H. 1999. Biostatistical analysis. $4^{\text {th }}$ Edition. Prentice Hall, Upper Saddle River, New Jersey. 

APPENDIX A

FISH BEHAVIOR DATA 

Table A.1. Repeated measures analysis of variance for time to first reaction to a startle stimulus, and post-hoc treatment comparisons

An * after a P-values denotes a statistically significant result

\begin{tabular}{lccc}
\hline & $\begin{array}{c}\mathrm{df} \\
\text { numerator, } \\
\text { Senominator }\end{array}$ & F-value & P-value \\
\hline Treatment & 2,25 & 15.71 & $<0.0001^{*}$ \\
$\quad$ Stimulus Time & 2,49 & 2.36 & 0.10 \\
Interaction & 4,49 & 0.92 & 0.46 \\
& & & \\
Treatment comparison & & $d f$ & -value \\
$\begin{array}{l}\text { Injection control vs } \\
\text { Tank control }\end{array}$ & & 25 & $0.0001^{*}$ \\
$\begin{array}{l}\text { Turbine passed vs } \\
\text { Tank control }\end{array}$ & & & \\
$\begin{array}{l}\text { Injection control vs } \\
\text { Turbine passed }\end{array}$ & & 25 & $0.0001^{*}$ \\
\hline
\end{tabular}


Table A.2. Analysis of variance of treatment effects, by startle stimulus time, for time to first reaction, and post-hoc comparisons

An * after a P-values denotes a statistically significant result

\begin{tabular}{|c|c|c|c|}
\hline Source of variation & $\begin{array}{c}\text { df } \\
\text { numerator, } \\
\text { denominator }\end{array}$ & F-value & P-value \\
\hline \multicolumn{4}{|c|}{1 min post-test startle stimulus } \\
\hline Treatment & 2,78 & 15.26 & $<0.0001^{*}$ \\
\hline Trial(treatment) & 25,78 & 0.99 & 0.4868 \\
\hline Treatment comparison & & $d f$ & $P$ - value \\
\hline $\begin{array}{l}\text { Injection control vs } \\
\text { Tank control }\end{array}$ & & 25 & $<0.05^{*}$ \\
\hline $\begin{array}{l}\text { Turbine passed vs } \\
\text { Tank control }\end{array}$ & & 25 & $<0.05^{*}$ \\
\hline $\begin{array}{l}\text { Injection control vs } \\
\text { Turbine passed }\end{array}$ & & 25 & $>0.05$ \\
\hline \multicolumn{4}{|c|}{5 min post-test startle stimulus } \\
\hline Treatment & 2,71 & 1.39 & 0.2671 \\
\hline Trial(treatment) & 24,71 & 1.81 & $0.0284^{*}$ \\
\hline $\begin{array}{l}\text { Injection control vs } \\
\text { Tank control }\end{array}$ & & 24 & $>0.05$ \\
\hline $\begin{array}{l}\text { Turbine passed vs } \\
\text { Tank control }\end{array}$ & & 24 & $>0.05$ \\
\hline $\begin{array}{l}\text { Injection control vs } \\
\text { Turbine passed }\end{array}$ & & 24 & $>0.05$ \\
\hline \multicolumn{4}{|c|}{15 min post-test startle stimulus } \\
\hline Treatment & 2,69 & 4.88 & $0.0149 *$ \\
\hline Trial(treatment) & 25,69 & 1.29 & 0.2011 \\
\hline $\begin{array}{l}\text { Injection control vs } \\
\text { Tank control }\end{array}$ & & 25 & $<0.05^{*}$ \\
\hline $\begin{array}{l}\text { Turbine passed vs } \\
\text { Tank control }\end{array}$ & & 25 & $<0.05^{*}$ \\
\hline $\begin{array}{l}\text { Injection control vs } \\
\text { Turbine passed }\end{array}$ & & 25 & $>0.05$ \\
\hline
\end{tabular}


Table A.3. Repeated measures analysis of variance for duration of reaction following a startle stimulus, and post-hoc treatment comparisons

An * after a P-values denotes a statistically significant result

\begin{tabular}{lccc}
\hline \multicolumn{1}{c}{$\begin{array}{c}\mathrm{df} \\
\text { Source of variation }\end{array}$} & $\begin{array}{c}\text { numerator, } \\
\text { denominator }\end{array}$ & F-value & P-value \\
\hline Treatment & 2,24 & 8.56 & $0.0016^{*}$ \\
Stimulus Time & 2,47 & 2.51 & 0.0922 \\
Interaction & 4,47 & 0.49 & 0.7420 \\
& & & \\
Treatment comparison & & $d f$ & \\
$\begin{array}{l}\text { Injection control vs } \\
\text { Tank control }\end{array}$ & & 24 & $0.0014^{*}$ \\
$\begin{array}{l}\text { Turbine passed vs } \\
\text { Tank control } \\
\text { Injection control vs } \\
\text { Turbine passed }\end{array}$ & & 24 & $0.0036^{*}$ \\
\hline
\end{tabular}


Table A.4. Analysis of variance of treatment effects, by startle stimulus time, for duration of reaction, and post-hoc comparisons

An * after a P-values denotes a statistically significant result

\begin{tabular}{|c|c|c|c|}
\hline Source of variation & $\begin{array}{c}\text { df } \\
\text { numerator, } \\
\text { denominator }\end{array}$ & F-value & P-value \\
\hline \multicolumn{4}{|c|}{1 min post-test startle stimulus } \\
\hline Treatment & 2,74 & 5.52 & $0.0108 *$ \\
\hline Trial(treatment) & 23,74 & 1.74 & $0.0388 *$ \\
\hline Treatment comparison & & $d f$ & $P$ - value \\
\hline $\begin{array}{l}\text { Injection control vs } \\
\text { Tank control }\end{array}$ & & 23 & $<0.05^{*}$ \\
\hline $\begin{array}{l}\text { Turbine passed vs } \\
\text { Tank control }\end{array}$ & & 23 & $<0.05^{*}$ \\
\hline $\begin{array}{l}\text { Injection control vs } \\
\text { Turbine passed }\end{array}$ & & 23 & \\
\hline \multicolumn{4}{|c|}{5 min post-test startle stimulus } \\
\hline Treatment & 2,67 & 2.59 & 0.0942 \\
\hline Trial(treatment) & 22,67 & 0.90 & 0.5983 \\
\hline $\begin{array}{l}\text { Injection control vs } \\
\text { Tank control }\end{array}$ & & 22 & $>0.05$ \\
\hline $\begin{array}{l}\text { Turbine passed vs } \\
\text { Tank control }\end{array}$ & & 22 & $>0.05$ \\
\hline $\begin{array}{l}\text { Injection control vs } \\
\text { Turbine passed }\end{array}$ & & 22 & $>0.05$ \\
\hline \multicolumn{4}{|c|}{15 min post-test startle stimulus } \\
\hline Treatment & 2, 66 & 5.68 & $0.0093 *$ \\
\hline Trial(treatment) & 23,66 & 1.38 & 0.1581 \\
\hline $\begin{array}{l}\text { Injection control vs } \\
\text { Tank control }\end{array}$ & & 23 & $<0.05^{*}$ \\
\hline $\begin{array}{l}\text { Turbine passed vs } \\
\text { Tank control }\end{array}$ & & 23 & $<0.05^{*}$ \\
\hline $\begin{array}{l}\text { Injection control vs } \\
\text { Turbine passed }\end{array}$ & & & $>0.05$ \\
\hline
\end{tabular}


Table A.5. Repeated measures analysis of variance for time taken to form the maximum C-shape after a startle stimulus, and post-hoc treatment comparisons

An * after a P-values denotes a statistically significant result

\begin{tabular}{lccc}
\hline & $\begin{array}{c}\text { df } \\
\text { numerator, } \\
\text { Source of variation }\end{array}$ & F-value & P-value \\
\hline Treatment & 2,25 & 20.30 & $<0.0001^{*}$ \\
$\quad$ Stimulus Time & 2,49 & 2.04 & 0.1416 \\
Interaction & 4,49 & 0.36 & 0.8387 \\
& & & \\
Treatment comparison & & $d f$ & \\
& & 25 & \\
$\quad$ Injection control vs & & & $<0.0001^{*}$ \\
$\quad \begin{array}{l}\text { Tank control } \\
\text { Turbine passed vs } \\
\text { Tank control } \\
\begin{array}{l}\text { Injection control vs } \\
\text { Turbine passed }\end{array}\end{array}$ & 25 & $<0.0001^{*}$ \\
\hline
\end{tabular}


Table A.6. Analysis of variance of treatment effects, by startle stimulus time, for time taken to form the maximum $\mathrm{C}$-shape, and post-hoc comparisons

An * after a P-values denotes a statistically significant result

\begin{tabular}{|c|c|c|c|}
\hline Source of variation & $\begin{array}{c}\text { df } \\
\text { numerator, } \\
\text { denominator }\end{array}$ & F-value & P-value \\
\hline \multicolumn{4}{|c|}{1 min post-test startle stimulus } \\
\hline Treatment & 2,75 & 13.84 & $<0.0001 *$ \\
\hline Trial(treatment) & 25,75 & 1.19 & 0.2776 \\
\hline Treatment comparison & & $d f$ & $P$ - value \\
\hline $\begin{array}{l}\text { Injection control vs } \\
\text { Tank control }\end{array}$ & & 25 & $<0.05^{*}$ \\
\hline $\begin{array}{l}\text { Turbine passed vs } \\
\text { Tank control }\end{array}$ & & 25 & $<0.05^{*}$ \\
\hline $\begin{array}{l}\text { Injection control vs } \\
\text { Turbine passed }\end{array}$ & & 25 & $>0.05$ \\
\hline \multicolumn{4}{|c|}{5 min post-test startle stimulus } \\
\hline Treatment & 2,70 & 4.67 & $0.0183^{*}$ \\
\hline Trial(treatment) & 24,70 & 1.87 & $0.0223 *$ \\
\hline $\begin{array}{l}\text { Injection control vs } \\
\text { Tank control }\end{array}$ & & 24 & $>0.05$ \\
\hline $\begin{array}{l}\text { Turbine passed vs } \\
\text { Tank control }\end{array}$ & & 24 & $<0.05^{*}$ \\
\hline $\begin{array}{l}\text { Injection control vs } \\
\text { Turbine passed }\end{array}$ & & & $>0.05$ \\
\hline \multicolumn{4}{|c|}{15 min post-test startle stimulus } \\
\hline Treatment & 2,71 & 9.17 & $0.0008 *$ \\
\hline Trial(treatment) & 25,71 & 1.10 & 0.3664 \\
\hline $\begin{array}{l}\text { Injection control vs } \\
\text { Tank control }\end{array}$ & & 25 & $<0.05^{*}$ \\
\hline $\begin{array}{l}\text { Turbine passed vs } \\
\text { Tank control }\end{array}$ & & 25 & $<0.05^{*}$ \\
\hline $\begin{array}{l}\text { Injection control } \\
\text { vs Turbine passed }\end{array}$ & & 25 & $>0.05$ \\
\hline
\end{tabular}


Table A .7. Repeated measures analysis of variance for time taken from maximum C-shape to the end of $\mathrm{C}$-shape behavior after a startle stimulus, and post-hoc treatment comparisons

\begin{tabular}{|c|c|c|c|}
\hline Source of variation & $\begin{array}{c}\mathrm{df} \\
\text { numerator, } \\
\text { denominator }\end{array}$ & F-value & P-value \\
\hline Treatment & 2,25 & 8.19 & $0.0018 *$ \\
\hline Stimulus Time & 2,49 & 4.16 & $0.0214 *$ \\
\hline Interaction & 2,49 & 1.00 & 0.4149 \\
\hline Treatment Comparison & & $d f$ & $P$ - value \\
\hline $\begin{array}{l}\text { Injection control vs } \\
\text { Tank control }\end{array}$ & & 25 & $0.0013 *$ \\
\hline $\begin{array}{l}\text { Turbine passed vs } \\
\text { Tank control }\end{array}$ & & 25 & $0.0088^{*}$ \\
\hline $\begin{array}{l}\text { Injection control vs } \\
\text { Turbine passed }\end{array}$ & & 25 & 0.6399 \\
\hline
\end{tabular}


Table A.8. Analysis of variance of treatment effects, by startle stimulus time, for time from maximum $\mathrm{C}$-shape to the end of $\mathrm{C}$-shape behavior, and post-hoc comparisons An * after a P-values denotes a statistically significant result

\begin{tabular}{|c|c|c|c|}
\hline Source of variation & $\begin{array}{c}\text { df } \\
\text { numerator, } \\
\text { denominator }\end{array}$ & F-value & P-value \\
\hline \multicolumn{4}{|c|}{1 min post-test startle stimulus } \\
\hline Treatment & 2,80 & 5.58 & $0.0097 *$ \\
\hline Trial(treatment) & 25,80 & 1.12 & 0.3377 \\
\hline Treatment comparison & & $d f$ & $P$ - value \\
\hline $\begin{array}{l}\text { Injection control vs } \\
\text { Tank control }\end{array}$ & & 25 & $<0.05^{*}$ \\
\hline $\begin{array}{l}\text { Turbine passed vs } \\
\text { Tank control }\end{array}$ & & 25 & $<0.05^{*}$ \\
\hline $\begin{array}{l}\text { Injection control vs } \\
\text { Turbine passed }\end{array}$ & & 25 & $>0.05$ \\
\hline \multicolumn{4}{|c|}{5 min post-test startle stimulus } \\
\hline Treatment & 2,75 & 0.94 & 0.4034 \\
\hline Trial(treatment) & 24,75 & 1.51 & 0.0914 \\
\hline $\begin{array}{l}\text { Injection control vs } \\
\text { Tank control }\end{array}$ & & 24 & $>0.05$ \\
\hline $\begin{array}{l}\text { Turbine passed vs } \\
\text { Tank control }\end{array}$ & & 24 & $>0.05$ \\
\hline $\begin{array}{l}\text { Injection control vs } \\
\text { Turbine passed }\end{array}$ & & 24 & $>0.05$ \\
\hline \multicolumn{4}{|c|}{15 min post-test startle stimulus } \\
\hline Treatment & 2,73 & 3.08 & 0.0620 \\
\hline Trial(treatment) & 25,73 & 1.15 & 0.3164 \\
\hline $\begin{array}{l}\text { Injection control vs } \\
\text { Tank control }\end{array}$ & & 25 & $>0.05$ \\
\hline $\begin{array}{l}\text { Turbine passed vs } \\
\text { Tank control }\end{array}$ & & 25 & $>0.05$ \\
\hline $\begin{array}{l}\text { Injection control vs } \\
\text { Turbine passed }\end{array}$ & & 25 & $>0.05$ \\
\hline
\end{tabular}


Table A.9. Repeated measures analysis of variance for ratio of closest distance between head and tail: total body length

An * after a P-values denotes a statistically significant result

\begin{tabular}{lccc}
\hline & $\begin{array}{c}\mathrm{df} \\
\text { numerator, } \\
\text { denominator }\end{array}$ & F-value & P-value \\
\hline Treatment & 2,25 & 0.36 & 0.7042 \\
Stimulus Time & 2,49 & 0.95 & 0.3946 \\
Interaction & 4,49 & 0.50 & 0.7388 \\
\hline
\end{tabular}

Table A.10. Chi-square tests of the independence of treatment and start position of fish to a startle stimulus

Values are frequencies and expected frequencies (in parentheses) of fish responses to the stimulus

\begin{tabular}{|c|c|c|c|c|c|}
\hline Response to stimulus & $\begin{array}{c}\text { Tank } \\
\text { control }\end{array}$ & $\begin{array}{c}\text { Injection } \\
\text { control }\end{array}$ & $\begin{array}{l}\text { Turbine } \\
\text { passed }\end{array}$ & $\begin{array}{l}\text { Row } \\
\text { total }\end{array}$ & Statistical values \\
\hline \multicolumn{6}{|c|}{1 min post-test startle stimulus } \\
\hline Parallel & $\begin{array}{c}6 \\
(5.2)\end{array}$ & $\begin{array}{c}14 \\
(16.8)\end{array}$ & $\begin{array}{c}15 \\
(13.0)\end{array}$ & 35 & \multirow{3}{*}{$\begin{array}{c}\chi^{2}=1.38 \\
d f=2 \\
p=0.5236\end{array}$} \\
\hline Perpendicular & $\begin{array}{c}10 \\
(10.8)\end{array}$ & $\begin{array}{c}38 \\
(35.1)\end{array}$ & $\begin{array}{c}25 \\
(27.0)\end{array}$ & 73 & \\
\hline Column total & 16 & 52 & 40 & 108 & \\
\hline \multicolumn{6}{|c|}{5 min post-test startle stimulus } \\
\hline Parallel & $\begin{array}{c}6 \\
(4.7)\end{array}$ & $\begin{array}{c}25 \\
(22.9)\end{array}$ & $\begin{array}{c}13 \\
(16.4)\end{array}$ & 44 & \multirow{3}{*}{$\begin{array}{c}\chi^{2}=2.17 \\
d f=2 \\
p=0.3380\end{array}$} \\
\hline Perpendicular & $\begin{array}{c}5 \\
(6.3)\end{array}$ & $\begin{array}{c}28 \\
(30.1)\end{array}$ & $\begin{array}{c}25 \\
(21.6)\end{array}$ & 58 & \\
\hline Column total & 11 & 53 & 38 & 102 & \\
\hline \multicolumn{6}{|c|}{15 min post-test startle stimulus } \\
\hline Parallel & $\begin{array}{c}6 \\
(6.5)\end{array}$ & $\begin{array}{c}23 \\
(22)\end{array}$ & $\begin{array}{c}15 \\
(15.5)\end{array}$ & 44 & \multirow{3}{*}{$\begin{array}{c}\chi^{2}=0.172 \\
d f=2 \\
p=0.9177\end{array}$} \\
\hline Perpendicular & $\begin{array}{c}9 \\
(8.5)\end{array}$ & $\begin{array}{c}28 \\
(29)\end{array}$ & $\begin{array}{c}21 \\
(20.5)\end{array}$ & 58 & \\
\hline Column total & 15 & 51 & 36 & 102 & \\
\hline
\end{tabular}


Table A.11 Fisher Exact tests of the independence of start position of fish and exhibition of $\mathrm{C}$-shape formation to a startle stimulus

Values are frequencies and expected frequencies (in parentheses) of fish responses to the stimulus

\begin{tabular}{|c|c|c|c|c|}
\hline $\begin{array}{c}\text { Response to } \\
\text { stimulus }\end{array}$ & Parallel & Perpendicular & Row total & Statistical values \\
\hline \multicolumn{5}{|c|}{1 min post-test startle stimulus } \\
\hline No & $\begin{array}{c}13 \\
(11.7)\end{array}$ & $\begin{array}{c}23 \\
(24.3)\end{array}$ & 36 & \\
\hline Yes & $\begin{array}{c}22 \\
(23.3)\end{array}$ & $\begin{array}{c}50 \\
(48.7)\end{array}$ & 72 & $\begin{array}{c}\mathrm{df}= \\
\mathrm{p}=0.663\end{array}$ \\
\hline Column total & 35 & 73 & 108 & \\
\hline \multicolumn{5}{|c|}{5 min post-test startle stimulus } \\
\hline No & $\begin{array}{c}19 \\
(17.7)\end{array}$ & $\begin{array}{c}22 \\
(23.3)\end{array}$ & 41 & \\
\hline Yes & $\begin{array}{c}25 \\
(26.3)\end{array}$ & $\begin{array}{c}36 \\
(34.7)\end{array}$ & 61 & $\begin{array}{c}\mathrm{df}=1 \\
\mathrm{p}=0.684\end{array}$ \\
\hline Column total & 44 & 58 & 102 & \\
\hline \multicolumn{5}{|c|}{15 min post-test startle stimulus } \\
\hline No & $\begin{array}{c}9 \\
(9.5)\end{array}$ & $\begin{array}{c}13 \\
(12.5)\end{array}$ & 22 & \\
\hline Yes & $\begin{array}{c}35 \\
(34.5)\end{array}$ & $\begin{array}{c}45 \\
(45.5)\end{array}$ & 80 & $\begin{array}{c}\mathrm{df}=1 \\
\mathrm{p}=1.00\end{array}$ \\
\hline Column total & 44 & 58 & 102 & \\
\hline
\end{tabular}




\section{Table A.12. Fisher Exact tests of the independence of treatment and direction of turn from a startle stimulus}

Responding fish either turned toward or away from the stimulus. Values are frequencies and expected frequencies (in parentheses) of fish responses to the stimulus. Note that cell frequencies were large enough to use the Chi-square test in the experiment when a stimulus was applied at $5 \mathrm{~min}$ post-treatment

\begin{tabular}{|c|c|c|c|c|c|}
\hline $\begin{array}{l}\text { Response to } \\
\text { stimulus }\end{array}$ & $\begin{array}{c}\text { Tank } \\
\text { control }\end{array}$ & $\begin{array}{c}\text { Injection } \\
\text { control }\end{array}$ & $\begin{array}{l}\text { Turbine } \\
\text { passed }\end{array}$ & Row total & $\begin{array}{c}\text { Statistical } \\
\text { values }\end{array}$ \\
\hline \multicolumn{6}{|c|}{1 min post-test startle stimulus } \\
\hline Away & $\begin{array}{c}5 \\
(8.4)\end{array}$ & $\begin{array}{c}20 \\
(19.4)\end{array}$ & $\begin{array}{c}21 \\
(18.1)\end{array}$ & 46 & \multirow{3}{*}{$\begin{array}{c}\chi^{2}=5.276 \\
d f=2 \\
p=0.374\end{array}$} \\
\hline Toward & $\begin{array}{c}8 \\
(4.6)\end{array}$ & $\begin{array}{c}10 \\
(10.6)\end{array}$ & $\begin{array}{c}7 \\
(9.9)\end{array}$ & 25 & \\
\hline Column total & 13 & 30 & 28 & 71 & \\
\hline \multicolumn{6}{|c|}{5 min post-test startle stimulus } \\
\hline Away & $\begin{array}{c}4 \\
(4.20)\end{array}$ & $\begin{array}{c}21 \\
(21.1)\end{array}$ & $\begin{array}{c}18 \\
(17.6)\end{array}$ & 43 & \multirow{3}{*}{$\begin{array}{c}\mathrm{df}=2 \\
\mathrm{p}=1.00\end{array}$} \\
\hline Toward & $\begin{array}{c}2 \\
(1.8)\end{array}$ & $\begin{array}{c}9 \\
(8.8)\end{array}$ & $\begin{array}{c}7 \\
(7.4)\end{array}$ & 18 & \\
\hline Column total & 6 & 30 & 25 & 61 & \\
\hline \multicolumn{6}{|c|}{15 min post-test startle stimulus } \\
\hline Away & $\begin{array}{c}9 \\
(7.7)\end{array}$ & $\begin{array}{c}29 \\
(28)\end{array}$ & $\begin{array}{c}18 \\
(20.3)\end{array}$ & 56 & \multirow{3}{*}{$\begin{array}{c}\mathrm{df}=2 \\
\mathrm{p}=0.467\end{array}$} \\
\hline Toward & $\begin{array}{c}2 \\
(3.3)\end{array}$ & $\begin{array}{c}11 \\
(12)\end{array}$ & $\begin{array}{c}11 \\
(8.7)\end{array}$ & 24 & \\
\hline Column total & 11 & 40 & 29 & 80 & \\
\hline
\end{tabular}




\section{Table A.13. Fisher Exact tests of the independence of start position of fish and direction of turn from the startle stimulus}

Values are frequencies and expected frequencies (in parentheses) of fish responses to the stimulus

\begin{tabular}{|c|c|c|c|c|}
\hline $\begin{array}{l}\text { Response to } \\
\text { stimulus }\end{array}$ & Parallel & Perpendicular & Row total & Statistical values \\
\hline \multicolumn{5}{|c|}{1 min post-test startle stimulus } \\
\hline Away & $\begin{array}{c}12 \\
(13.6)\end{array}$ & $\begin{array}{c}34 \\
(32.4)\end{array}$ & 46 & \\
\hline Toward & $\begin{array}{c}9 \\
(7.4)\end{array}$ & $\begin{array}{c}16 \\
(17.6)\end{array}$ & 25 & $\begin{array}{c}\mathrm{df}=1 \\
\mathrm{p}=0.423\end{array}$ \\
\hline Column total & 21 & 50 & 71 & \\
\hline \multicolumn{5}{|c|}{5 min post-test startle stimulus } \\
\hline Away & $\begin{array}{c}17 \\
(17.6)\end{array}$ & $\begin{array}{c}26 \\
(25.4)\end{array}$ & 43 & \\
\hline Toward & $\begin{array}{c}8 \\
(7.4)\end{array}$ & $\begin{array}{c}10 \\
(10.6)\end{array}$ & 18 & $\begin{array}{c}\mathrm{df}=1 \\
\mathrm{p}=0.780\end{array}$ \\
\hline Column total & 25 & 36 & 61 & \\
\hline \multicolumn{5}{|c|}{15 min post-test startle stimulus } \\
\hline Away & $\begin{array}{c}20 \\
(24.5)\end{array}$ & $\begin{array}{c}36 \\
(31.5)\end{array}$ & 56 & \\
\hline Toward & $\begin{array}{c}15 \\
(10.5)\end{array}$ & $\begin{array}{c}9 \\
(13.5)\end{array}$ & 24 & $\begin{array}{c}\mathrm{df}=1 \\
\mathrm{p}=0.048\end{array}$ \\
\hline Column total & & & & \\
\hline
\end{tabular}




\section{Table A.14. Fisher Exact tests of the independence of treatment and angle of turn following a startle stimulus}

Values are frequencies and expected frequencies (in parentheses) of fish responses to the stimulus. Note that when the stimulus was applied at 15 min post-treatment, no fish turned an angle of $180 \mathrm{E}$

\begin{tabular}{|c|c|c|c|c|c|}
\hline $\begin{array}{l}\text { Turn angle } \\
\text { (degrees) }\end{array}$ & $\begin{array}{l}\text { Tank } \\
\text { control }\end{array}$ & $\begin{array}{c}\text { Injection } \\
\text { control }\end{array}$ & $\begin{array}{l}\text { Turbine } \\
\text { passed }\end{array}$ & Row total & $\begin{array}{c}\text { Statistical } \\
\text { values }\end{array}$ \\
\hline \multicolumn{6}{|c|}{1 min post-test startle stimulus } \\
\hline 0 & $\begin{array}{c}2 \\
(0.5)\end{array}$ & $\begin{array}{c}1 \\
(1.2)\end{array}$ & $\begin{array}{c}0 \\
(1.2)\end{array}$ & 3 & \multirow{6}{*}{$\begin{array}{c}\mathrm{df}=8 \\
\mathrm{p}=0.483\end{array}$} \\
\hline 45 & $\begin{array}{c}7 \\
(6.0)\end{array}$ & $\begin{array}{c}14 \\
(13.7)\end{array}$ & $\begin{array}{c}12 \\
(13.3)\end{array}$ & 33 & \\
\hline 90 & $\begin{array}{c}3 \\
(4.9)\end{array}$ & $\begin{array}{c}11 \\
(11.2)\end{array}$ & $\begin{array}{c}13 \\
(10.9)\end{array}$ & 27 & \\
\hline 135 & $\begin{array}{c}1 \\
(1.4)\end{array}$ & $\begin{array}{c}4 \\
(3.3)\end{array}$ & $\begin{array}{c}3 \\
(3.2)\end{array}$ & 8 & \\
\hline 180 & $\begin{array}{c}0 \\
(0.2)\end{array}$ & $\begin{array}{c}0 \\
(0.4)\end{array}$ & $\begin{array}{c}1 \\
(0.4)\end{array}$ & 1 & \\
\hline Column total & 13 & 30 & 29 & 72 & \\
\hline \multicolumn{6}{|c|}{5 min post-test startle stimulus } \\
\hline 0 & $\begin{array}{c}0 \\
(0.2)\end{array}$ & $\begin{array}{c}2 \\
(1.0)\end{array}$ & $\begin{array}{c}0 \\
(0.8)\end{array}$ & 2 & \multirow{6}{*}{$\begin{array}{c}\mathrm{df}=8 \\
\mathrm{p}=0.467\end{array}$} \\
\hline 45 & $\begin{array}{c}1 \\
(2.5)\end{array}$ & $\begin{array}{c}13 \\
(12.3)\end{array}$ & $\begin{array}{c}11 \\
(10.2)\end{array}$ & 25 & \\
\hline 90 & $\begin{array}{c}4 \\
(2.7)\end{array}$ & $\begin{array}{c}13 \\
(13.8)\end{array}$ & $\begin{array}{c}11 \\
(11.5)\end{array}$ & 28 & \\
\hline 135 & $\begin{array}{c}0 \\
(0.4)\end{array}$ & $\begin{array}{c}2 \\
(2.0)\end{array}$ & $\begin{array}{c}2 \\
(1.6)\end{array}$ & 4 & \\
\hline 180 & $\begin{array}{c}1 \\
(0.2)\end{array}$ & $\begin{array}{c}0 \\
(1.0)\end{array}$ & $\begin{array}{c}1 \\
(0.8)\end{array}$ & 2 & \\
\hline Column total & 6 & 30 & 25 & 61 & \\
\hline \multicolumn{6}{|c|}{15 min post-test startle stimulus } \\
\hline 0 & $\begin{array}{c}1 \\
(0.1)\end{array}$ & $\begin{array}{c}0 \\
(0.5)\end{array}$ & $\begin{array}{c}0 \\
(0.4)\end{array}$ & 1 & \multirow{5}{*}{$\begin{array}{c}\mathrm{df}=6 \\
\mathrm{p}=0.300\end{array}$} \\
\hline 45 & $\begin{array}{c}5 \\
(4.4)\end{array}$ & $\begin{array}{c}17 \\
(16)\end{array}$ & $\begin{array}{c}10 \\
(11.6)\end{array}$ & 32 & \\
\hline 90 & $\begin{array}{c}4 \\
(5.9)\end{array}$ & $\begin{array}{c}22 \\
(21.5)\end{array}$ & $\begin{array}{c}17 \\
(15.6)\end{array}$ & 43 & \\
\hline 135 & $\begin{array}{c}1 \\
(0.5)\end{array}$ & $\begin{array}{c}1 \\
(2)\end{array}$ & $\begin{array}{c}2 \\
(1.4)\end{array}$ & 4 & \\
\hline Column total & 11 & 40 & 29 & 80 & \\
\hline
\end{tabular}


Table A.15. Fisher Exact tests of the independence of start position of fish and turn angle following a startle stimulus

\begin{tabular}{|c|c|c|c|c|}
\hline $\begin{array}{l}\text { Turn angle } \\
\text { (degrees) }\end{array}$ & Parallel & Perpendicular & Row total & Statistical values \\
\hline \multicolumn{5}{|c|}{1 min post-test startle stimulus } \\
\hline 0 & $\begin{array}{c}2 \\
(0.9)\end{array}$ & $\begin{array}{c}1 \\
(2.1)\end{array}$ & 3 & \multirow{5}{*}{$\begin{array}{c}d f=4 \\
p=0.069\end{array}$} \\
\hline 45 & $\begin{array}{c}12 \\
(10.1)\end{array}$ & $\begin{array}{c}21 \\
(22.9)\end{array}$ & 33 & \\
\hline 90 & $\begin{array}{c}4 \\
(8.2)\end{array}$ & $\begin{array}{c}23 \\
(18.7)\end{array}$ & 27 & \\
\hline 135 & $\begin{array}{c}4 \\
(2.4)\end{array}$ & $\begin{array}{c}4 \\
(5.6)\end{array}$ & 8 & \\
\hline 180 & $\begin{array}{c}0 \\
(0.3)\end{array}$ & $\begin{array}{c}1 \\
(0.7)\end{array}$ & 1 & \\
\hline
\end{tabular}

Column total

22

50

72

5 min post-test startle stimulus

0

45

90

135

180

Column total

0
$(0.8)$

10

(10.3)

12

(11.5)

1

(1.6)

2

$(0.8)$

5 min post-test startle stimulus

2

(1.2)

15

(14.7)

16

(16.5)

3

(2.4)

0

(1.2)
2

25

28

$\mathrm{df}=4$

$\mathrm{p}=0.428$
4

2

36

61

15 min post-test startle stimulus

0

1

(0.4)

$45 \quad 16$

(14)

90

16

(18.8)

135

\section{0}

(0.6)

16

(18)

27

(24.2)

2

(2.2)
4
2
$(1.7)$

35

45

$$
\begin{gathered}
\mathrm{df}=3 \\
\mathrm{p}=0.492
\end{gathered}
$$

43

$35-45$

80 
ORNL/TM-2003/288

\section{INTERNAL DISTRIBUTION}

1. M. S. Bevelhimer

2. M. A. Brown

3-7. G. F. Cada

8. C. C. Coutant

9. G. K. Jacobs

10. M. K. McCracken

11. Gail Morris
12-16. M. G. Ryon
17. M. J. Sale
18-19. J. G. Smith
20-21. ESD Library
22. ORNL Central Research Library
23. ORNL Laboratory Records-RC
24. ORNL Laboratory Records-OSTI

\section{EXTERNAL DISTRIBUTION}

25. Jim Ahlgrimm, EE-2B, US Department of Energy, Office of Wind \& Hydropower Technologies, Room 5H/072 FORS, 1000 Independence Ave., SW, Washington DC 20585

26. Paul Bernhardt, Reliant Energy, Inc., 225 Greenfield Parkway, Suite 201, Liverpool, NY 13088

27. Peggy Brookshier, U.S. Department of Energy, Idaho Operations Office, 850 Energy Drive MS-1220, Idaho Falls, ID 83401-1563

28. Stephen Brown, Grant County PUD, P.O. Box 878 Ephrata, WA 98823

29. Tom Carlson, Pacific Northwest National Laboratory, 620 S.W. $5^{\text {th }}$ Avenue, Suite 810, Portland, OR 97204

30. Peter Christensen, R2 Resource Consultants, 15250 NE $95^{\text {th }}$ Street, Redmond, WA 98052

31. Bill Christman, Chelan County PUD, 327 North Wenatchee Ave., P.O. Box 1231, Wenatchee, WA 98801

32. Ron Corso, Mead \& Hunt, Inc., 904 Farley Court, S.E., Vienna, VA 22180-5916

33. Dennis D. Dauble, Pacific Northwest National Laboratory, Battelle Boulevard, P.O. 999, Richland, WA 99352

34. Doug Dixon, EPRI, 7905 Berkeley Drive, Gloucester Point, VA 23062

35. Steve Doret, Stone \& Webster Consultants, Inc., One Bowdoin Square, Boston, MA 02114

36. Laurie L. Ebner, U.S. Army Corps of Engineers, P.O. Box 2946, Portland, OR 97208-2946

37. John W. Ferguson, National Marine Fisheries Service, Northwest Fisheries Center, 2725 Montlake Boulevard, East Seattle, WA 98112

38-42. Peter Goldman, EE-2B, US Department of Energy, Office of Wind \& Hydropower Technologies, Room 5H/072 FORS, 1000 Independence Ave., SW, Washington DC 20585

43. Scott Hendricks, Georgia Power Company, Environmental Laboratory, 5131 Maner Road, Smyrna, GA 30080

44. Jennifer Hill, Federal Energy Regulatory Commission, 888 First Street, N.E., Washington, DC 20426

45. Richard T. Hunt, Idaho National Engineering \& Environmental Laboratory, 2525 Fremont Ave., Idaho Falls, ID 83415-3830

46. Mike Langeslay, U.S. Army Corps of Engineers, P.O. Box 2946 , Portland, OR 97208-2946

47. Charles R. Liston, Consultant, 168 Ralston Road, Bedford, KY 40006

48. Edward Meyer, National Marine Fisheries Service, 525 N.E. Oregon St., Suite 500, Portland, OR $97232-2737$

49. Lawrence B. Moore, Southern Services Company, 42 Inverness Center Parkway, Birmingham, AL 35242

50. Thomas R Murphy, Federal Hydro Projects, Bonneville Power Administration, PGF/6th Floor, P.O. Box 3621, Portland, OR 97208-3621 
51. Alex Haro, U.S. Geological Survey, Department of Interior, One Migratory Way, P.O. Box 796, Turner Falls, MA 01376

52. Joe O'Hagan, California Energy Commission, PIER Environmental Area, 1516 9th St., MS 50, Sacramento, CA 95814-5512

53. Forrest Olson, CH2M Hill, P.O. Box 91500, Bellevue, WA 98009

54. Rock D. Peters, U.S. Army Corps of Engineers, 333 S.W. First Avenue, P.O. Box 2946, Portland, OR 97208-2946

55. William L. Preslan, Coastal and Hydraulics Laboratory, Engineer Research and Development Center, Waterways Experiment Station, 3909 Halls Ferry Road, Vicksburg, MS 39180

56. Marshall Richmond, Pacific Northwest National Laboratory, P.O. Box 999 / MS K9-33, Richland, WA 99352

57. Wayne Rogers, Synergics, Inc., 191 Main Street, Annapolis, MD 21401

58. Lee Sheldon, NLink Corp., 510 SW $3^{\text {rd }}$ Ave., Suite 200, Portland, OR 97204-2507

59. Garold L. Sommers, Idaho National Engineering \& Environmental Laboratory, 2525 Fremont Ave., Idaho Falls, ID 83415-3830

60. Fotis Sotiropoulos, School of Civil and Environmental Engineering, Georgia Institute of Technology, Atlanta, GA 30332-0355

61. Steve Wenke, Avista Corp., 1411 East Mission Avenue, Spokane, WA 99220-3727

62. Rod Wittinger, U.S. Army Corps of Engineers, 333 SW First Avenue, P.O. Box 2946, Portland, OR 97208-2946 


\section{A Strong Energy Portfolio for a Strong America}

Energy efficiency and clean, renewable energy will mean a stronger economy, a cleaner environment, and greater energy independence for America. By investing in technology breakthroughs today, our nation can look forward to a more resilient economy and secure future.

Far-reaching technology changes will be essential to America's energy future. Working with a wide array of state, community, industry, and university partners, the U.S. Department of Energy's Office of Energy Efficiency and Renewable Energy invests in a portfolio of energy technologies that will:

- Conserve energy in the residential, commercial, industrial, government, and transportation sectors

- Increase and diversify energy supply, with a focus on renewable domestic sources

- Upgrade our national energy infrastructure

- Facilitate the emergence of hydrogen technologies as vital new "energy carriers."

\section{The Opportunities}

Biomass Program

Using domestic, plant-derived resources to meet our fuel, power, and chemical needs

Building Technologies Program

Homes, schools, and businesses that use less energy, cost less to operate, and ultimately, generate as much power as they use

Distributed Energy \& Electric Reliability Program

A more reliable energy infrastructure and reduced need for new power plants

Federal Energy Management Program

Leading by example, saving energy and taxpayer dollars in federal facilities

FreedomCAR \& Vehicle Technologies Program

Less dependence on foreign oil, and eventual transition to an emissions-free, petroleum-free vehicle

Geothermal Technologies Program

Tapping the Earth's energy to meet our heat and power needs

Hydrogen, Fuel Cells \& Infrastructure Technologies Program

Paving the way toward a hydrogen economy and net-zero carbon energy future

Industrial Technologies Program

Boosting the productivity and competitiveness of U.S. industry through improvements in energy and environmental performance

Solar Energy Technology Program

Utilizing the sun's natural energy to generate electricity and provide water and space heating

Weatherization \& Intergovernmental Program

Accelerating the use of today's best energy-efficient and renewable technologies in homes, communities, and businesses

Wind \& Hydropower Technologies Program

Harnessing America's abundant natural resources for clean power generation

To learn more, visit www.eere.energy.gov 